\title{
THE BIOLOGY OF Trillium cernuum (Liliaceae)
}

TOM REAUME, 212 Sherburn St., Winnipeg, Manitoba R3G 2 K6

\section{Introduction}

The Whip-poor-will-flower, Trillium cernuum, is a native perennial that grows in deciduous wooded areas, coniferous swamps and moist thickets along edges of bogs, rivers and streams. This rhizomatous, long-lived, vernal herb produces a single white flower per stem which develops into a red berry. Hanging on a reflexed pedicel, the perfect flower faces the forest floor and is hidden beneath an apical whorl of three subsessile leaves (Fig. 1).

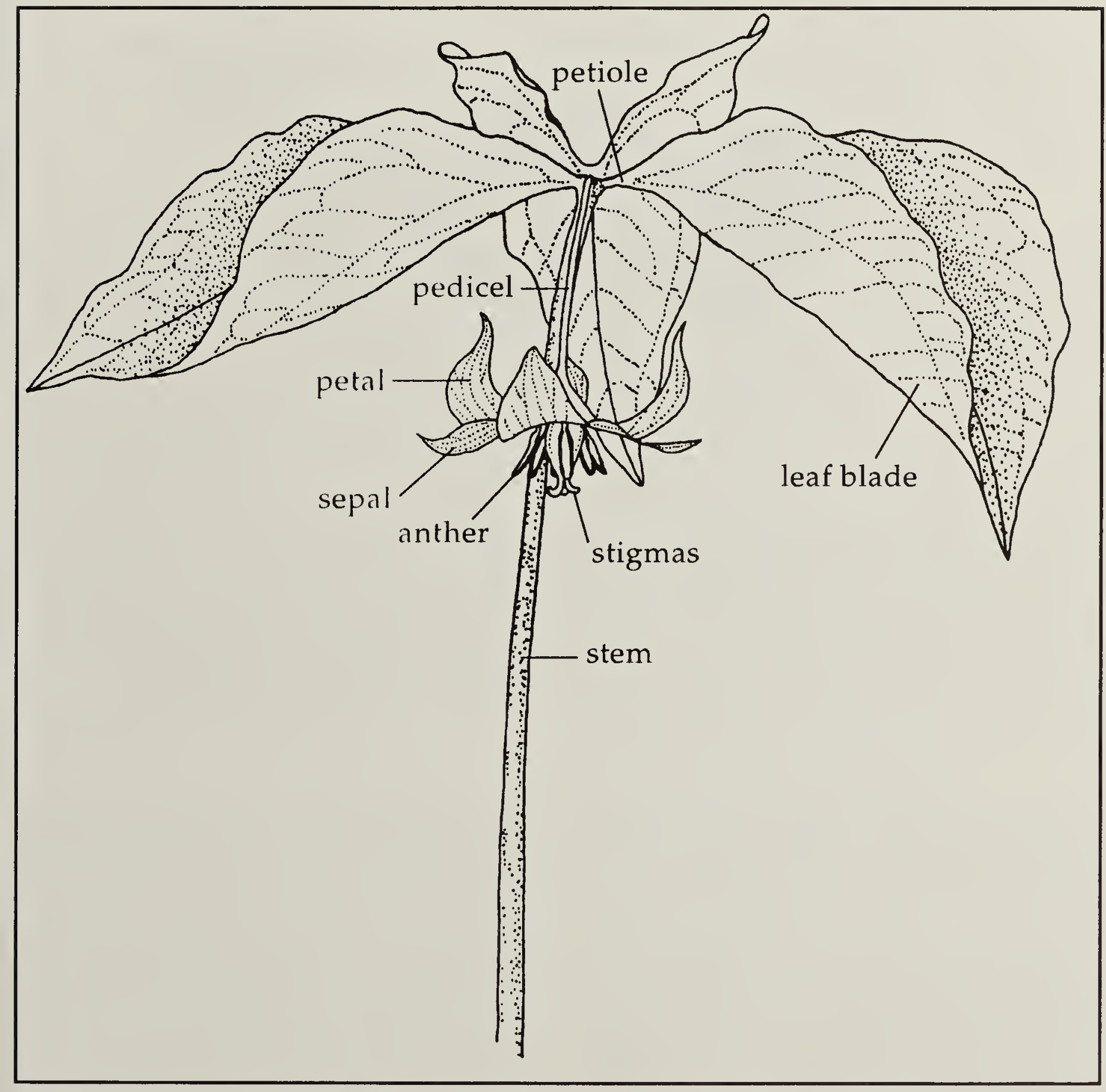

Figure 1. Upper plant form of a single-flower (SF) Trillium cernuum. $x 1$ 
T. cernuum is the only trillium species in Manitoba and Saskatchewan. In Canada, its range extends from eastern Saskatchewan to Newfoundland, occupying parts of eight provinces. In the United States it is found in 21 states, from the Dakotas to Virginia and northward along the Atlantic coast to Maine (Fig. 2). Reports of T. cernuum in Georgia and Alabama appear in earlier publications ${ }^{15}$ but have since been negated. environmental factors, microhabitat and age of the plants. This is also true for six populations of Stinking-benjamin, T. erectum, in Ontario, in which there was much phenotypic variation among and within populations, and about one-third of the size variations in floral parts was dependent on plant size within a population. ${ }^{37}$

In 2001 and 2002, I undertook a study of

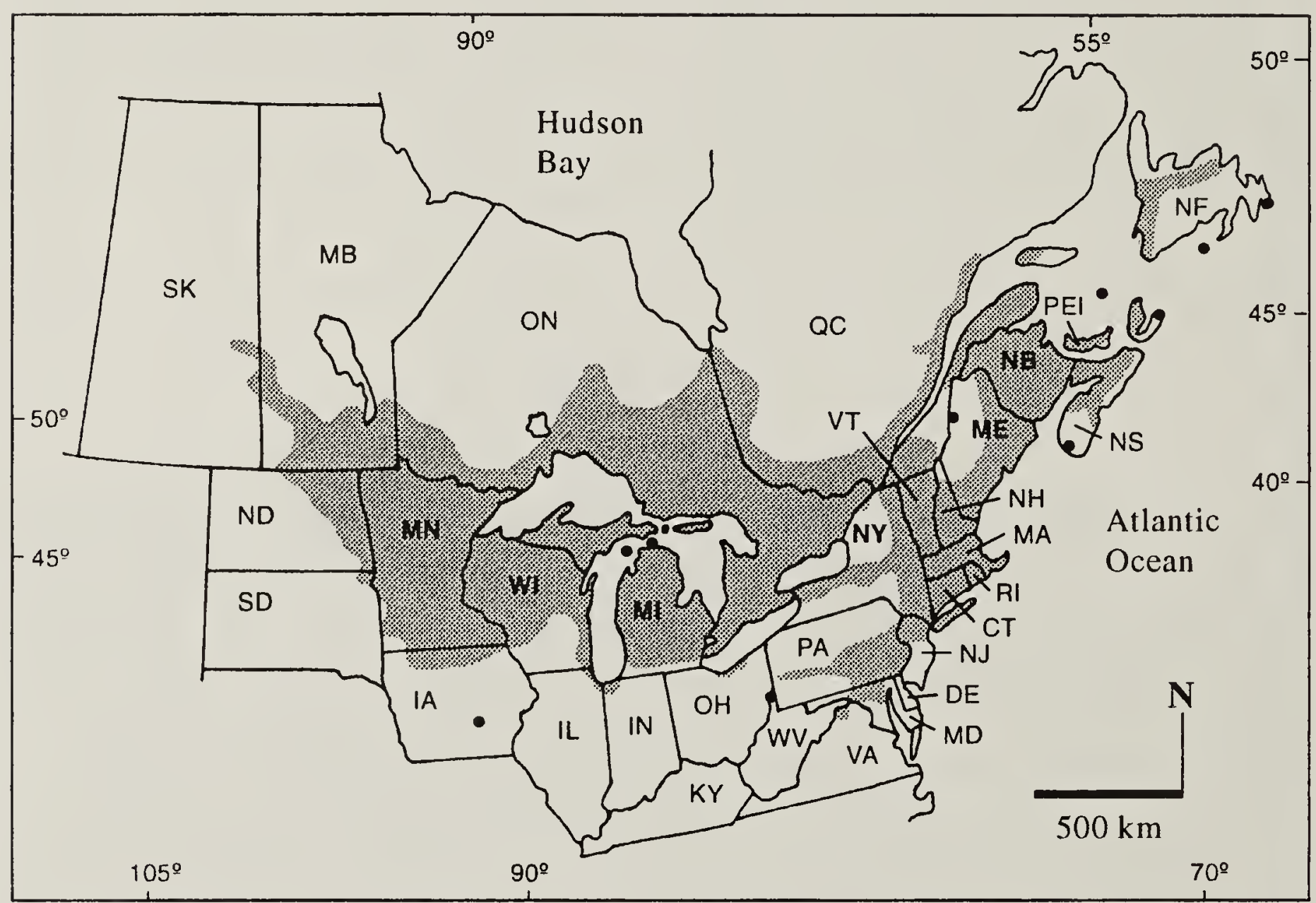

Figure 2. The range of the Whip-poor-will-flower, Trillium cernuum in Canada and the U.S.A. The following references were used to compile the range shown in Map 1: $3,4,6,7,9,20,22,27,29,30,33,36,38,39$ and 45 in addition to information from 38 herbaria (listed in the acknowledgements) contacted directly by the author.

Kartesz lists 39 species of the genus Trillium in North America. ${ }^{24}$ The Cases list 43 species. ${ }^{6}$ Both, however, agree that the two previously recognized varieties of $T$. cernuum, - variety cernuum, a small-flowered eastern plant and variety macranthum, the large-flowered western plant - are not discrete enough to be maintained. The size variations throughout the Whip-poor-will-flower's range are due to a combination of genetic and
T. cernuum to describe its habitat, range, habit, phenology, pollination, age, plant parts, reproduction and seed dispersal in one isolated population in Winnipeg. Relationships to herbs, shrubs and trees were also noted as were predation by mammals and interactions with invertebrates. This article presents some of the results of this study along with an analysis of ageing Whip-poor-will-flower plants using characteristics of the rhizome. 
This study was undertaken for two reasons: to provide a more complete account than is currently available in floras, and to provide baseline information about this species. Only three small papers have been dedicated to the biology of the Whip-poorwill-flower. ${ }^{10,11,18}$

All common and scientific botanical names used in this article follow those in the Biota of North America Program (BONAP). ${ }^{24}$

The ink drawings were completed over two years from fresh specimens, using a dissecting microscope when necessary to view fine details. The drawings are labeled to identify parts mentioned in the text.

\section{Materials and methods}

Field study site

A wild population of Trillium cernuum was studied at Assiniboine Park in Winnipeg $\left(49^{\circ} 52^{\prime} \mathrm{N}, 97^{\circ} 15^{\prime} \mathrm{W}\right)$ in southern Manitoba. The population forms a natural community in a second-growth deciduous forest of Burr Oak (Quercus macrocarpa), Green Ash (Fraxinus pennsylvanica), American Elm (Ulmus americana), and American Basswood (Tilia americana). About 23,000 Whip-poor-will-flower plants grow over about $9,500 \mathrm{~m}^{2}$ (trails excluded) along the south shore of the Assiniboine River immediately east of the manicured English Garden. T. cernuum occupies an elevated, non-rocky, flat to undulating riverbank which is rarely flooded. Numerous walking/ bicycle trails (paved, gravel, and natural) fragment this woodland population.

The site is about $232 \mathrm{~m}$ in elevation. The frost-free period averages 121 days. The average date for the last spring frost is 23 May and the first autumnal frost, 22 September. The average annual rainfall is $41 \mathrm{~cm}$ and snowfall $126 \mathrm{~cm}$. May through September are usually without snow cover. The deepest snow cover occurs in January and averages $32 \mathrm{~cm}^{34}$

\section{Plant Categories}

The Whip-poor-will-flowers were assigned to eight categories based on growth

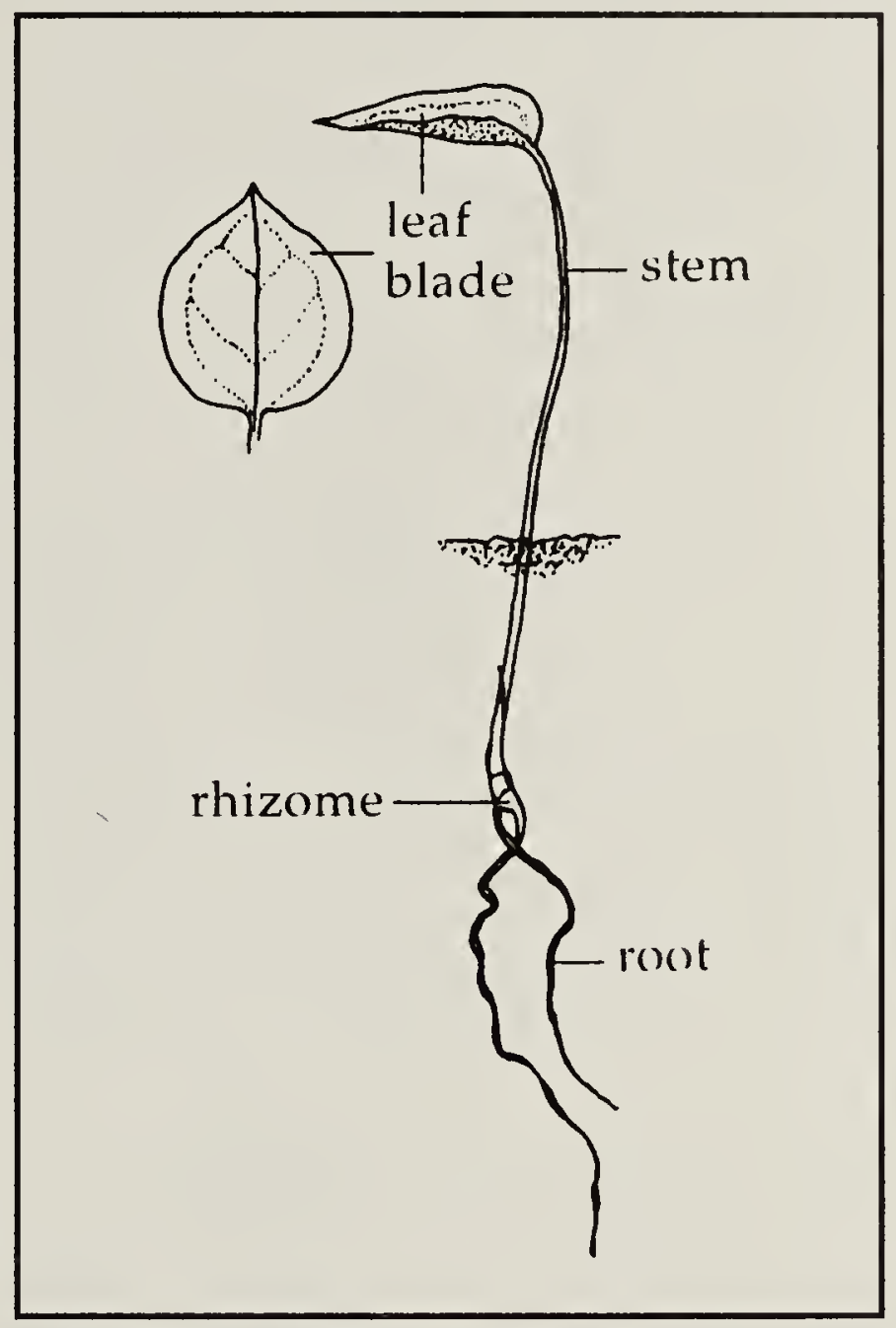

Figure 3. Vegetative plant with one leaf (V1), first appearing above the ground in its second spring. $x 1$

form, which are referred to throughout this paper by these abbreviations:

(V1) vegetative, 1 leaf: young vegetative plants with a single stem and one leaf (Fig. 3).

(V2) vegetative, 2 leaves: young vegetative plants with a single stem and two terminal leaves (Fig. 4).

(V3) vegetative, 3 leaves: vegetative plant with one stem and three leaves (Fig. 5). This was the most abundant growth form.

(V4) vegetative, 4 leaves: vegetative plant with a stem and four leaves in an apical whorl. Only one plant of this growth form was located.

(DV) vegetative doubles: vegetative plants with two stems $(<5 \mathrm{~mm}$ apart at ground level) arising from the apex of one rhizome; each stem has three leaves. 


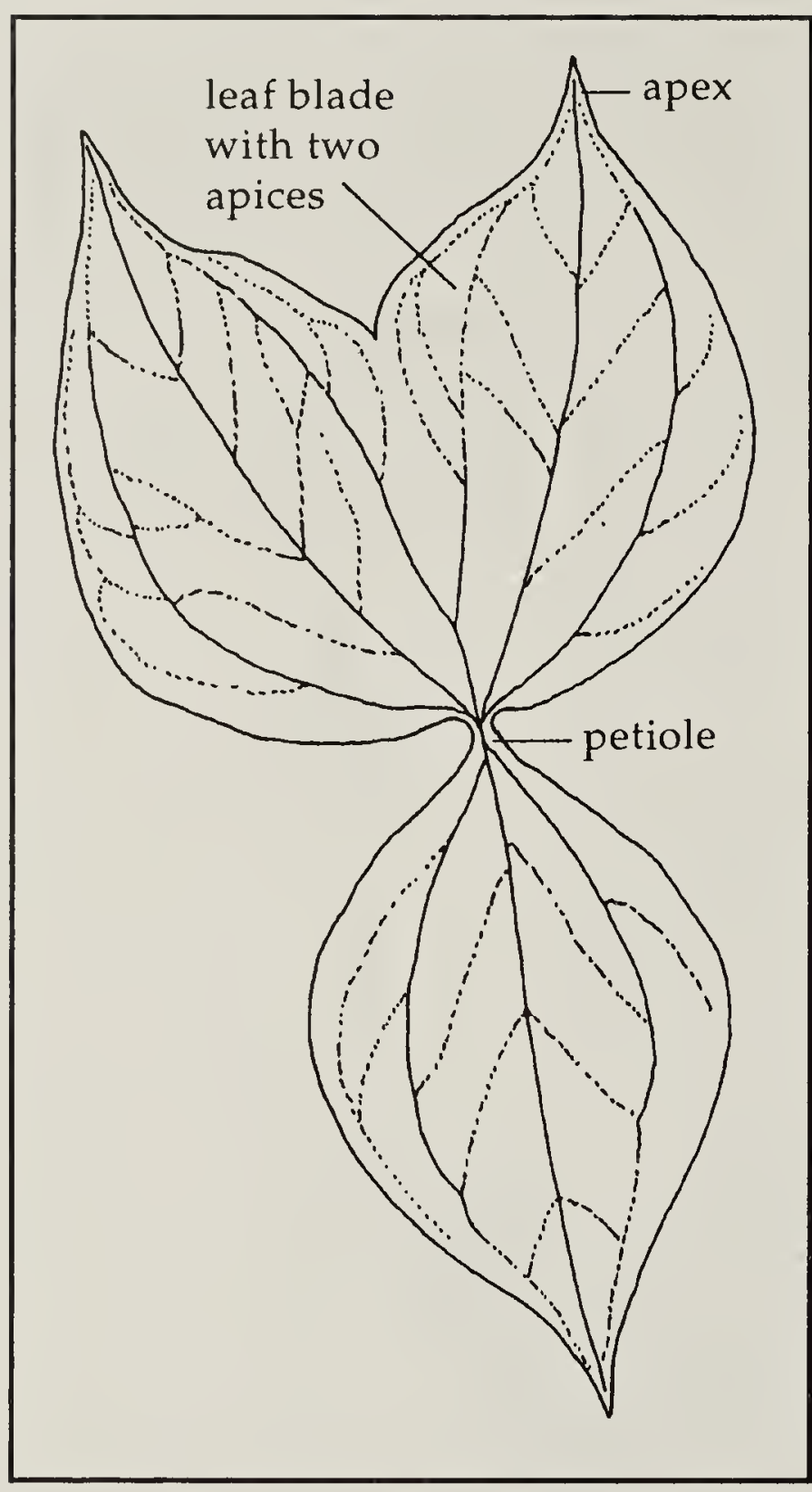

Figure 4. Vegetative plant with two leaves (V2), as seen from above.

(SF) single-flower: plants with one stem, a flower and three leaves (Fig. 1).

(half DF) half double-flower: plants with paired stems and each stem has three leaves but one stem carries a flower and the other stem is vegetative with an undeveloped flower $<10 \mathrm{~mm}$ long atop the stem where the petioles meet.

(DF) double-flower: plants with paired stems from a single rhizome and each stem has three leaves and one flower.

\section{Field Procedures}

The field work period lasted from 1 May to mid-October in 2001 and 2002.

Sample areas Eight randomly-placed quadrats and several two meter wide transects, along with both systematic and

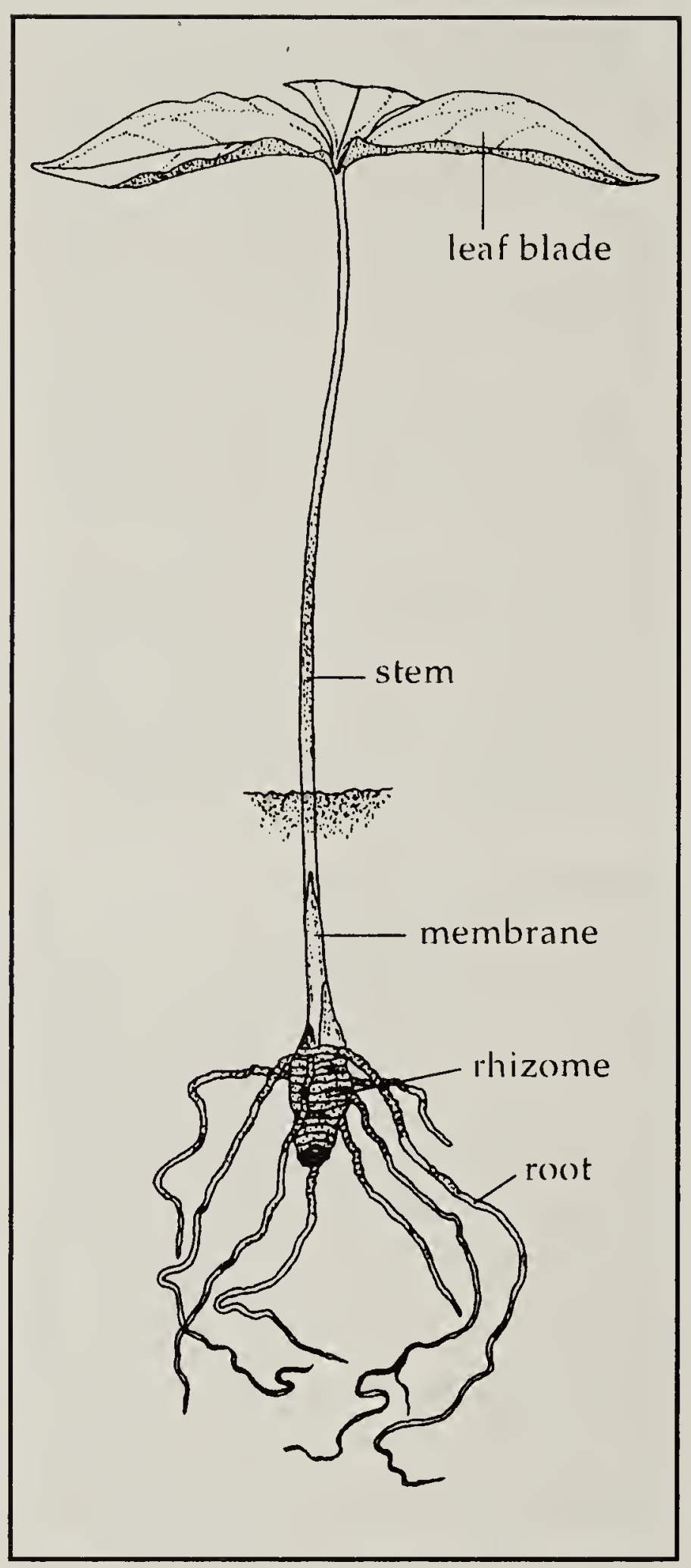

Figure 5. Vegetative plant with three leaves (V3). $x 0.8$

casual searches, were used to sample the population in May through September. Systematic and casual searches provided data on the double plant categories not sampled adequately by the quadrats and transects, as well as the smallest and largest plants in each category and phenology. The one V4 plant (vegetative with four leaves) was also located in a casual search. Compacted trails prohibited the growth of Whip-poor-willflowers and were not included in any sampling technique. The eight $2 \times 4 \mathrm{~m}$ 
quadrats were positioned on 14 May 2001 as the plants were beginning to flower. The long axis of four quadrats ran north-south and four, east-west.

Measurement of plant parts In 2001, all Whip-poor-will-flowers within each quadrat were counted, measured and mapped. For plant parts in multiples, i.e., sepals, petals, leaves and stamens (Figs. 6 \& 7), only one member of each group was measured on each plant. The leaf opposite the pedicel was

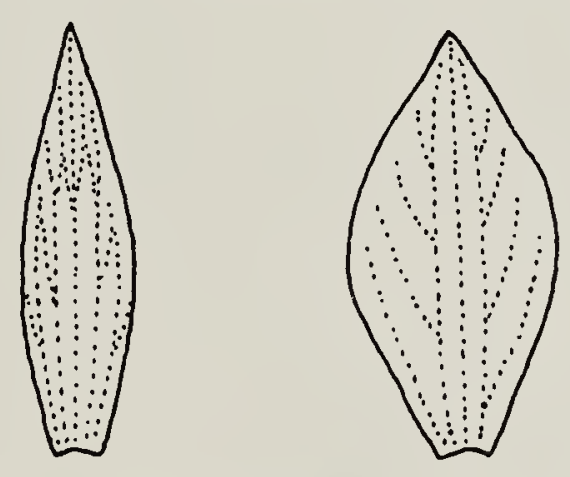

Figure 6. Perianth parts: green sepal (left) and white petal (right). $\times 1$

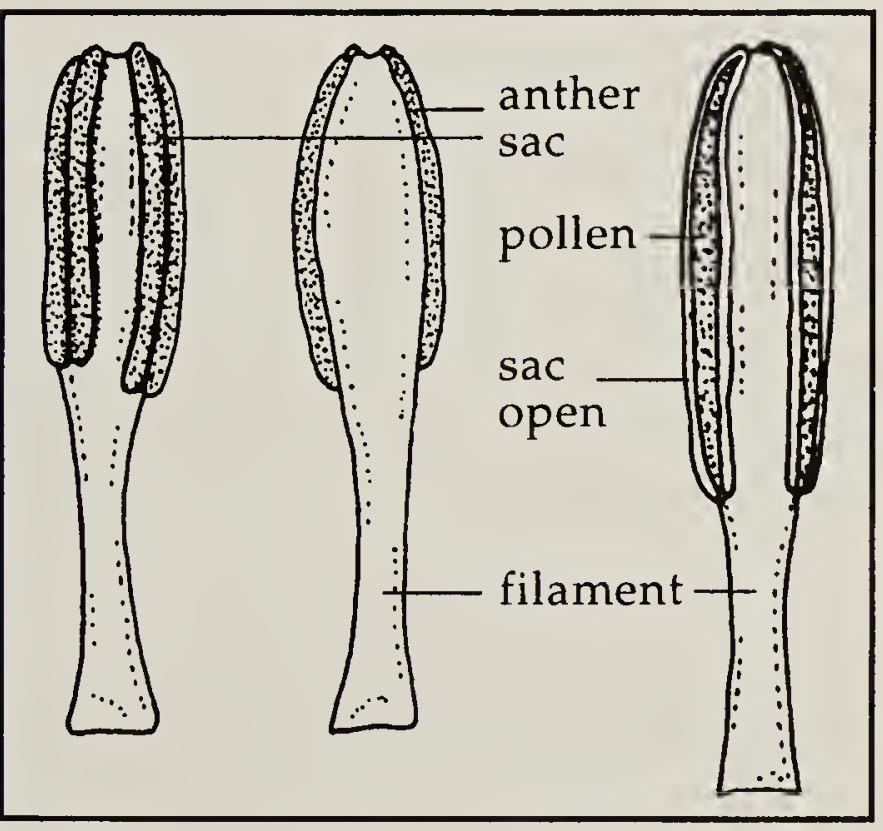

Figure 7. Stamens before (left pair), and at (right), anthesis. $x 5$

measured when a flower developed. Plants in the quadrats were measured on six days from 18-27 May 2001. As this was too early to measure stem, leaf and pedicel which were still growing and about $15 \%$ below their full expression, these were measured in early July 2001. Callipers were used to measure widths of stems near the ground and pedicels midway along their length. For double-flower (DF) plants, flowers were measured in late May 2001 shortly after opening. Plant parts other than flowers were measured in late June 2002.

Ageing experiment Outside the quadrats, ten plants in each of four categories (V1, V3, $\mathrm{SF}$ and $\mathrm{DF}$ ) and a range of sizes were selectively sampled in July-August 2002 for ageing by features of their rhizomes.

Plant density The distances from each trillium to the nearest trillium and nearest non-trillium (herb, shrub and tree) were measured for plants in quadrats and some transects. Diameter of the nearest shrub was obtained about $1 \mathrm{~cm}$ above ground for those $<50 \mathrm{~cm}$ tall; at the $10 \mathrm{~cm}$ height for those in the $50-100 \mathrm{~cm}$ range; and at the $50 \mathrm{~cm}$ height for shrubs $>100 \mathrm{~cm}$. Diameters of trees were taken at breast height (dbh).

Ovules and seeds For single-flower (SF) plants, ovules per pistil were counted in early June 2001 before much expansion took place. Plump, almost ripe seeds were counted in late July and early August 2001 to determine the number of seeds per berry and percentage of seed set. For double-flower (DF) plants, nearly ripe seeds were counted in late July to early August 2001. Fruit width and length were obtained on 18 August 2002, about a week before fruit began to fall from the plants.

Predation From 13 May through 8 June 2001, I measured trillium stem bases recently browsed by White-tailed Deer. Distances browsed stems to the nearest trillium were also noted.

\section{Results and Discussion}

Phenology in 2001

3 May: Trillium cernuum first appear above the snowless ground, leaves erect around the erect flower bud (Fig. 8); 14-28 May: flowering period; 13 June: fertilized ovules are about $1 \mathrm{~mm}$ long, the pistils white except for a blush at the base of the stigmas, 


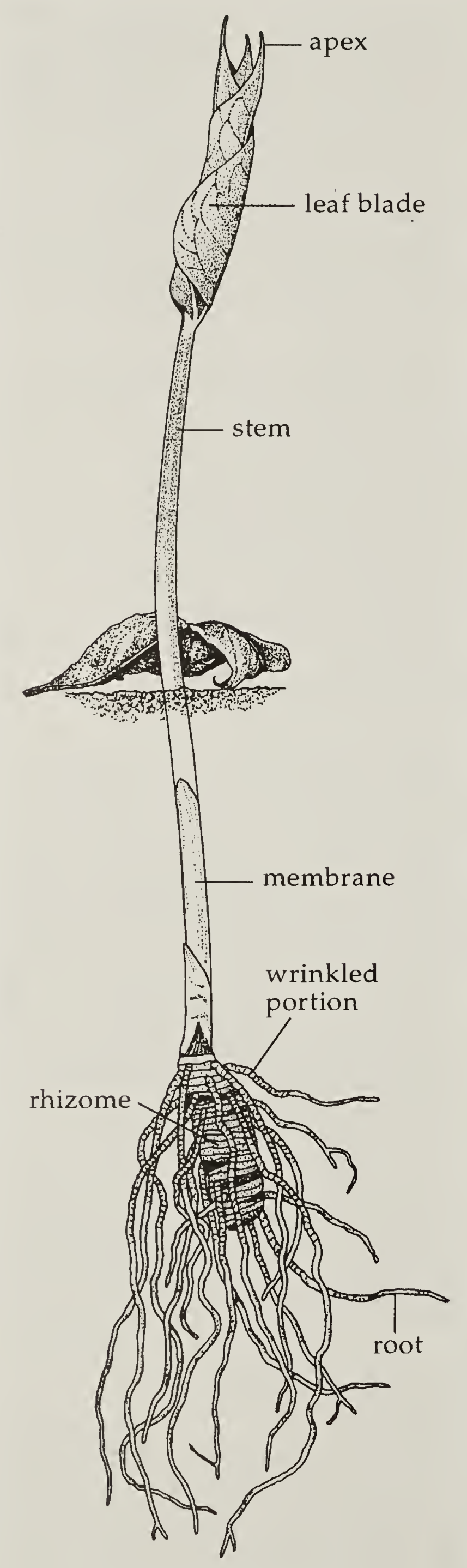

Figure 8. Trillium cernuum emerging, 3 May 2001. $x 0.8$ the crown buds are 3-8 mm long; 29 June: ovules are white and most 2-2.8 mm long, soft and milky, with pale yellow elaiosomes about $1.5 \mathrm{~mm}$ long (Fig. 9); 8 July: ovaries pink; 20 July: ovaries red, dull; 7 August:

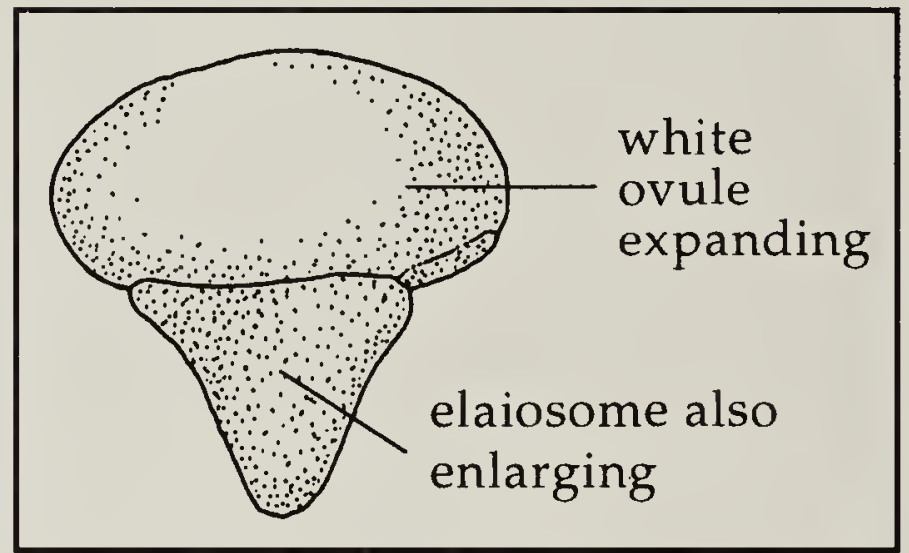

Figure 9. Growing white ovule and its pale yellow elaiosome, 1 July 2001. x 10

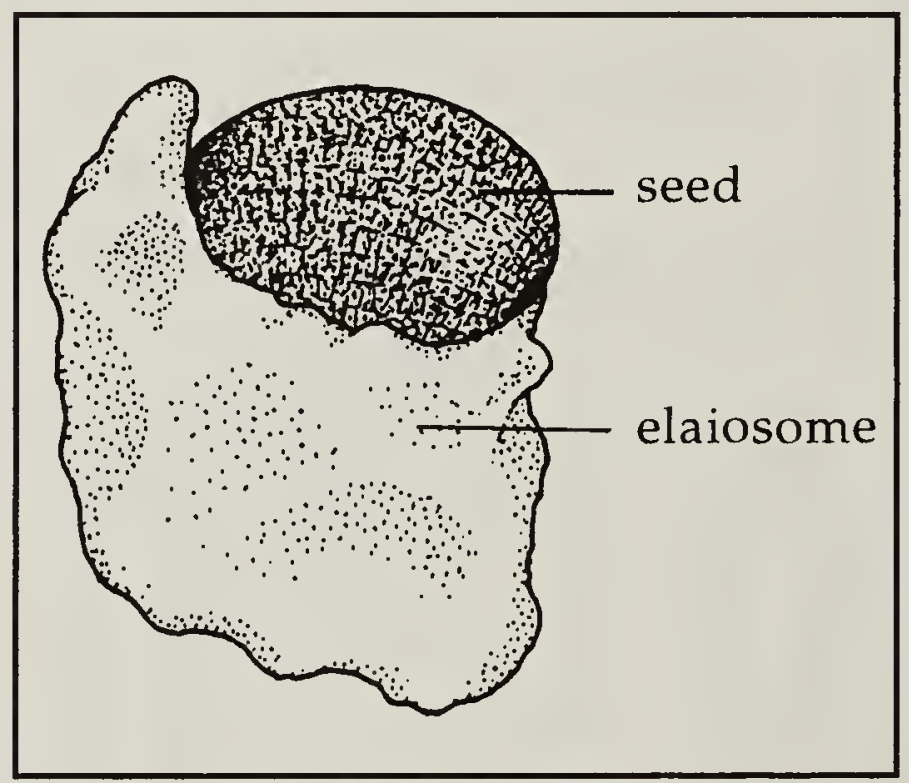

Figure 10. Seed with attached elaiosome, mid-August. $x 8$

some seeds brown, elaiosomes pale yellow and stiff (Fig. 10); 13 August: berries shiny, red and still attached to plants; 20-27 August: ripe fruit drops, the elaiosomes are mushy and the sepals mostly green; 5 September: crown buds continue to grow, leaves are still green on many vegetative and reproductive plants; 15 September: crown buds are white and $2-5 \mathrm{~cm}$ long, the longest buds on double-flower (DF) plants have their tips several $\mathrm{mm}$ above ground, deciduous tree leaves begin to fall, the first light frost occurred a few days earlier; 10 October: no upright trillium plants remain, a fresh layer of fallen deciduous tree leaves covers the 
Of special interest were the three vegetative, three-leaf plants in 2001 which emerged as small double-flower plants in 2002. Had these three plants carried a single flower before 2001 , or did they skip the singleflower (SF) phase and go directly to the DF category?

It also appears that older plants do not maintain their double-flower status forever. The largest double-flower (DF) plant in 2001 reverted to a large double-vegetative (DV) plant in 2002. Elsewhere, on one rhizome of a double-flower plant the three previous years produced large paired stem scars but the scars don't indicate if the aerial double stems bore flowers.
In New Hampshire, large Stinkingbenjamin plants also underwent some categorical changes over two years: V3 to V3 $(2 \%)$; V3 to SF (1\%); SF to SF $(85 \%)$; SF to DF (2\%); DF to SF (6\%); and DF to DF (4\%). From 1979 to 1980 , no flowering plants changed to a vegetative state. ${ }^{8}$ Overall, the populations remain fairly stable from year to year according to short term research.

\section{Description of plant parts}

Tables 1 and 2 present comparative measurements of stems, leaf blades, pedicels, flowers and flower parts of Trillium cernuum. Other plant parts are described below.

\begin{tabular}{|c|c|c|c|c|c|c|c|}
\hline $\begin{array}{l}\text { Category } \\
\text { (Vegetative) }\end{array}$ & $\begin{array}{l}n= \\
\text { \# of } \\
\text { stems }\end{array}$ & $\begin{array}{l}\text { Sten } \\
\text { length }\end{array}$ & width & $\begin{array}{l}\text { Leaf } B \\
\text { length }\end{array}$ & $\begin{array}{l}\text { lade } \\
\text { width }\end{array}$ & $\begin{array}{l}\text { Pedicel } \\
\text { length }\end{array}$ & $\begin{array}{c}\text { Flower } \\
\text { length width }\end{array}$ \\
\hline V1 (1-leaf) & 84 & $\begin{array}{l}6.0 \\
2.1-10.2\end{array}$ & $\begin{array}{l}0.1 \\
0.04-0.15\end{array}$ & $\begin{array}{l}3.4 \\
1.3-5.8\end{array}$ & $\begin{array}{l}2.8 \\
0.8-5.8\end{array}$ & & \\
\hline V2 (2-leaf) & 8 & $\begin{array}{l}8.6 \\
7.2-10.3\end{array}$ & $\begin{array}{l}0.14 \\
0.1-0.2\end{array}$ & $\begin{array}{l}4.1 \text { (1 pt) } \\
3.1-5.6 \\
4.1 \text { (2 pts) } \\
3.2-5.5\end{array}$ & $\begin{array}{l}2.4 \\
1.8-3.4 \\
3.7 \\
2.5-5.6\end{array}$ & & \\
\hline V3 (3-leaf) & 107 & $\begin{array}{l}17.5 \\
5.8-29.9\end{array}$ & $\begin{array}{l}0.22 \\
0.1-0.32\end{array}$ & $\begin{array}{l}7.4 \\
3.3-11\end{array}$ & $\begin{array}{l}5.5 \\
1.7-10.2\end{array}$ & $0.03-0.2$ & $0.1-0.75$ \\
\hline V4 (4-leaf) & 1 & 19.5 & & 7.2 & 5.4 & & \\
\hline $\begin{array}{l}\text { DV } \\
\text { (Double-vegetative) }\end{array}$ & 10 & $\begin{array}{l}33.1 \\
26.2-39.2\end{array}$ & & $\begin{array}{l}8.6 \\
7.6-10.3\end{array}$ & $\begin{array}{l}8.3 \\
6.5-10.7\end{array}$ & & $0.4-0.7$ \\
\hline $\begin{array}{l}\text { (Flowering) } \\
\text { SF (Single-flower) }\end{array}$ & 103 & $\begin{array}{l}32.8 \\
22.8-50\end{array}$ & $\begin{array}{l}0.38 \\
0.25-0.68\end{array}$ & $\begin{array}{l}10.6 \\
6.5-15\end{array}$ & $\begin{array}{l}9.7 \\
6.1-15.8\end{array}$ & $\begin{array}{l}4.1 \\
2.7-7.2\end{array}$ & $\begin{array}{l}2.2 \\
1.8-3.2\end{array}$ \\
\hline $\begin{array}{l}\text { Half DF } \\
\text { (Half Double-flower) }\end{array}$ & 4 & $\begin{array}{l}\text { Flowering } \\
31.7 / 25.4\end{array}$ & $\begin{array}{c}\text { vegetative } \\
0.39 / 0.35\end{array}$ & $\begin{array}{l}\text { Flowering } \\
10.6 / 9.9\end{array}$ & $\begin{array}{l}\text { I vegetative } \\
8.7 / 8.2\end{array}$ & & \\
\hline $\begin{array}{l}\text { DF } \\
\text { (Double-flower) }\end{array}$ & 128 & $\begin{array}{l}33.9 \\
23-46.6\end{array}$ & $\begin{array}{l}0.5 \\
0.3-0.7\end{array}$ & $\begin{array}{l}10.9 \\
8-15.5\end{array}$ & $\begin{array}{l}10.4 \\
7-16.2\end{array}$ & $\begin{array}{l}3.7 \\
2.6-5.4\end{array}$ & $\begin{array}{ll}2.6 \quad(n=28) & 3.9 \\
2-3.8 & 2.8-5.8\end{array}$ \\
\hline
\end{tabular}

Table 1. Measurements (in $\mathrm{cm}$ ) of Trillium cernuum plants growing in quadrats in Assiniboine Park, Winnipeg; means above ranges. $\mathrm{Pt}=$ point on a leaf.

\begin{tabular}{|l|ll|ll|ll|l|}
\hline $\begin{array}{l}\text { Category } \\
\text { (Flowering) }\end{array}$ & $\begin{array}{l}\text { Sepal } \\
\text { length }\end{array}$ & width & \multicolumn{2}{l|l|l|}{$\begin{array}{l}\text { Petal } \\
\text { length width }\end{array}$} & $\begin{array}{l}\text { Fruit } \\
\text { length } \text { width }\end{array}$ & $\begin{array}{l}\text { \# seeds } \\
\text { per berry }\end{array}$ \\
\hline SF (n=103) & 2.0 & 0.7 & 2.3 & 1.2 & 1.5 & 1.8 & $40(n=110)$ \\
(Single-flo.) & $1.6-3.5$ & $0.6-0.9$ & $1.8-3.5$ & $1-2$ & $1-2$ & $0.9-2.5$ & $11-158$ \\
\hline DF (n=28) & 2.5 & 0.9 & 2.7 & 1.4 & 1.7 & 2.1 & $80(n=26)$ \\
(Double-flo.) & $1.8-3.4$ & $0.5-1.2$ & $2.1-3.7$ & $1.1-2$ & $1-2.6$ & $1.4-2.7$ & $38-132$ \\
\hline
\end{tabular}

Table 2. Flower parts and fruit measurements (in $\mathrm{cm}$ ) of single-flower (SF) and doubleflower (DF) plants growing in quadrats in Assiniboine Park, Winnipeg; means above ranges. 
Undeveloped flowers These occurred on V3, DV and half-DF plants and were most noticeable on tall vegetative stems (Fig. 12). On small V3 plants, a tiny flower $1-1.5 \mathrm{~mm}$ long appears as a white dot to the unaided eye. Under a dissecting microscope, it has a white perianth about $1 \mathrm{~mm}$ long. In large undeveloped flowers, the imbricate, dry flower parts are brown atop a $1.5-2 \mathrm{~mm}(8$ $\mathrm{mm}$ in one case) long green pedicel. These closed flowers consist of erect sepals and petals, and stamens about $2 \mathrm{~mm}$ long around a slightly shorter pistil. No undeveloped flowers existed on Dwarf White Wakerobin, T. nivale, in Ohio. ${ }^{31}$

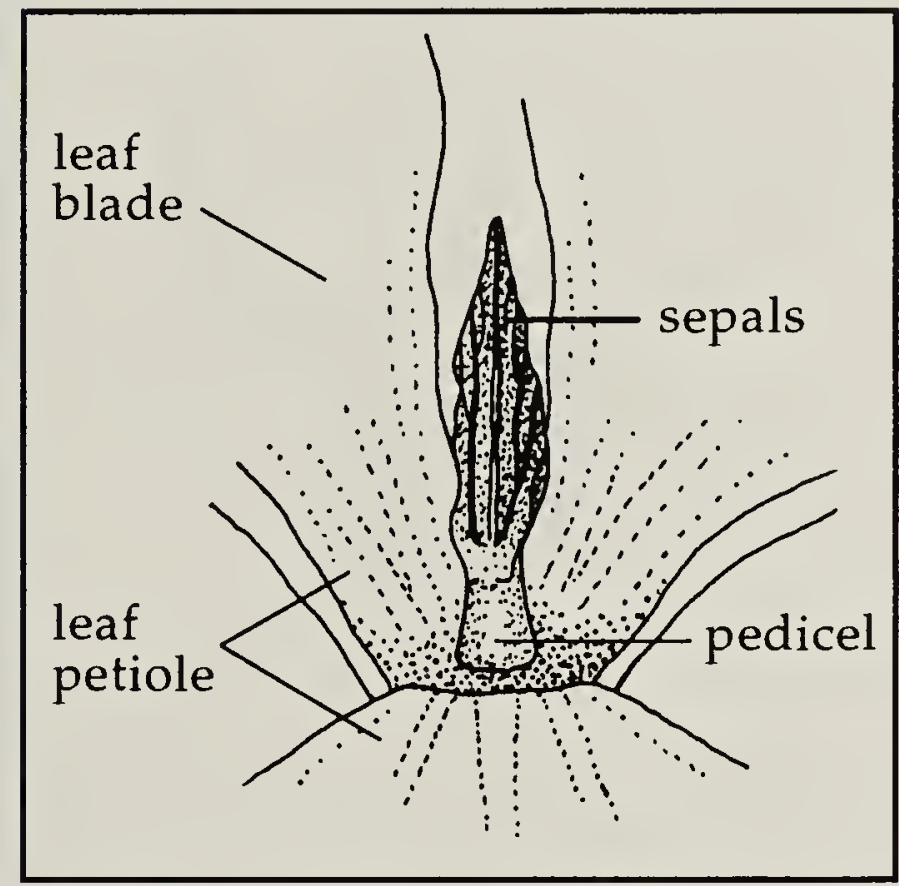

Figure 12. An undeveloped erect flower at the stem apex of a tall three-leaf plant (V3) where the three petioles meet. $x 3$

Stamens Stamens number six (58\%), three $(4 \%)$, or five $(38 \%)$, and develop opposite each sepal and each petal. Stamen length is $7-12 \mathrm{~mm}$. When only three stamens develop, they are opposite the outer whorl of three sepals. The filaments are white, slightly curved and about as long as the curved anthers. The stamens usually extend to the top of the three recurved stigmas. The anther sacs are usually purple (sometimes pale yellow) and attached along their full length to the sides of the stout $3-5 \mathrm{~mm}$ long filaments (Fig. 7). The sacs are 4-7 mm long and begin to split 12 or more hours after the flower petals open. Takahashi describes the pollen as white (I see fresh T. cernuum pollen as whitish tan) and 19-31 microns in diameter, smooth and of subtype IV with granulate exine ornamentation. The surface granules are of two types: large ones 1.0 micron in diameter and small, more numerous granules $<0.1$ micron in diameter. ${ }^{44}$

Pistil. The pistil consists of a tricarpic ovary, with a $2 \mathrm{~mm}$ long style (persistent in fruit) which branches abruptly into three stigmas (Fig. 13). The ovary is white and 6-

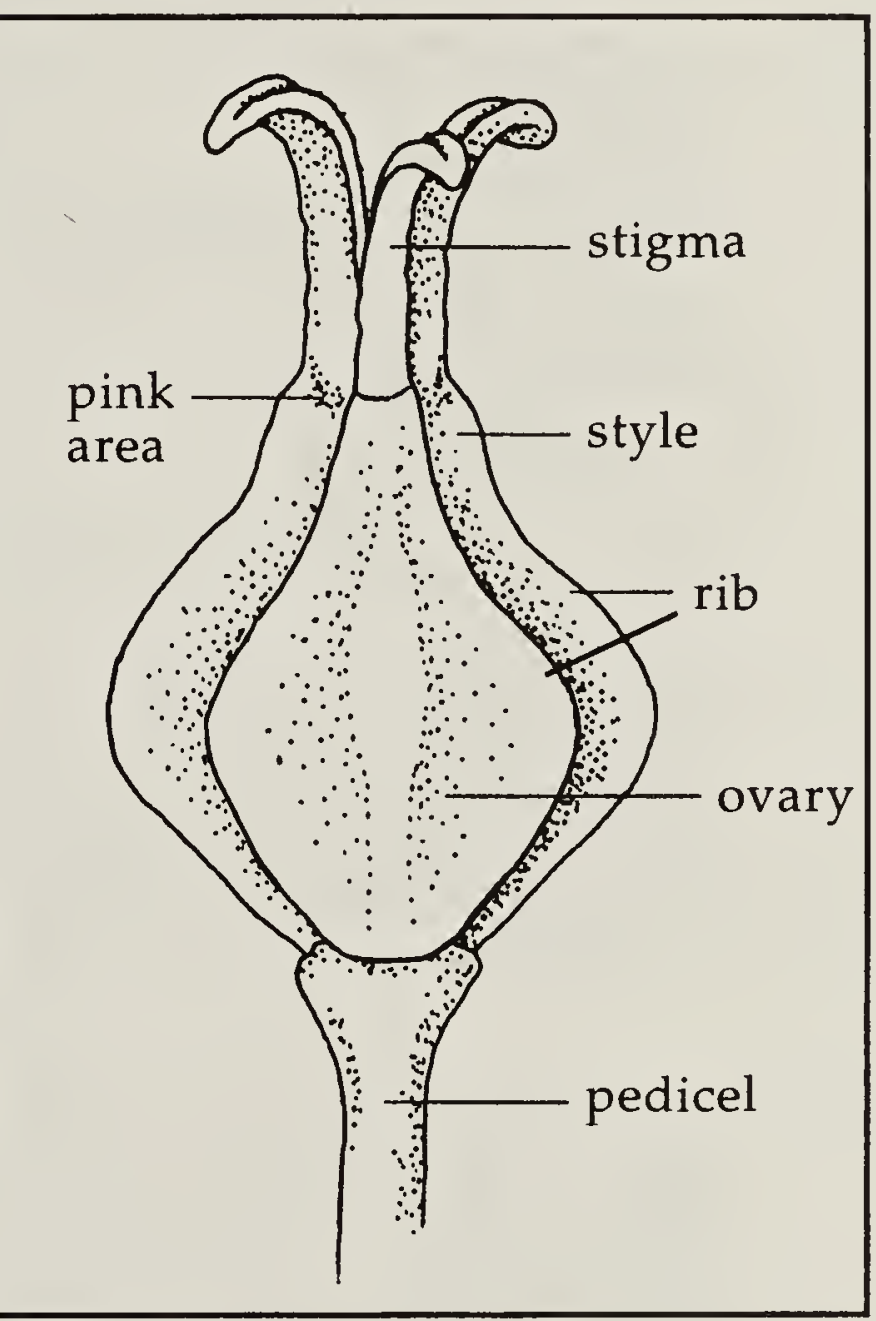

Figure 13. Superior pistil at anthesis with perianth and stamens removed. $x 5$

ribbed with a mean length of $10 \mathrm{~mm}$ (7-16) and a width of $6 \mathrm{~mm}(5-10)$. The ribs, a continuation from the outer margins of the three stigmas, are erect to slightly leaning. The three sides of the ovary opposite the sepals are less concave than the sides opposite the petals and have a low vertical line which marks the center of the locule inside (Fig. 14). The stigmas are white, recurved and $3-4 \mathrm{~mm}$ long by $4-9 \mathrm{~mm}$ wide (all three measured together). 


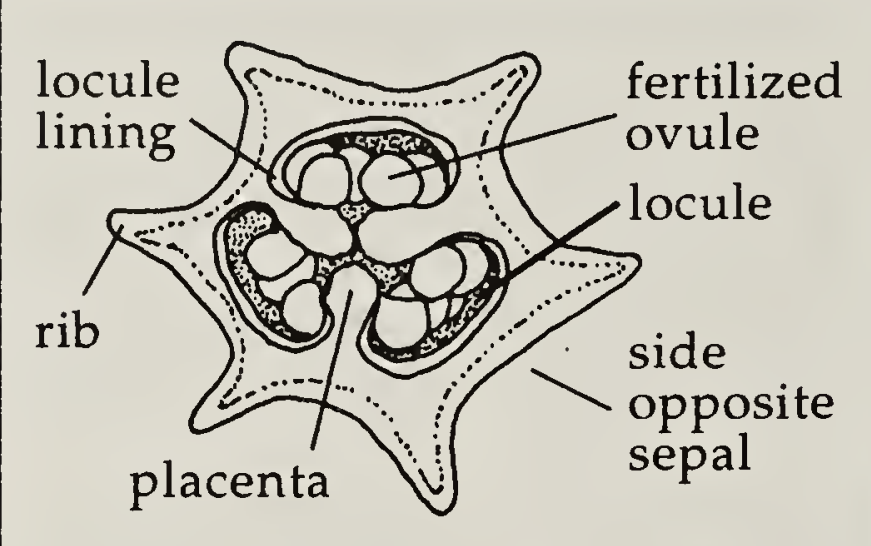

Figure 14. Cross-section of an ovary about 1 week after anthesis, 3 June 2002. $x 5$

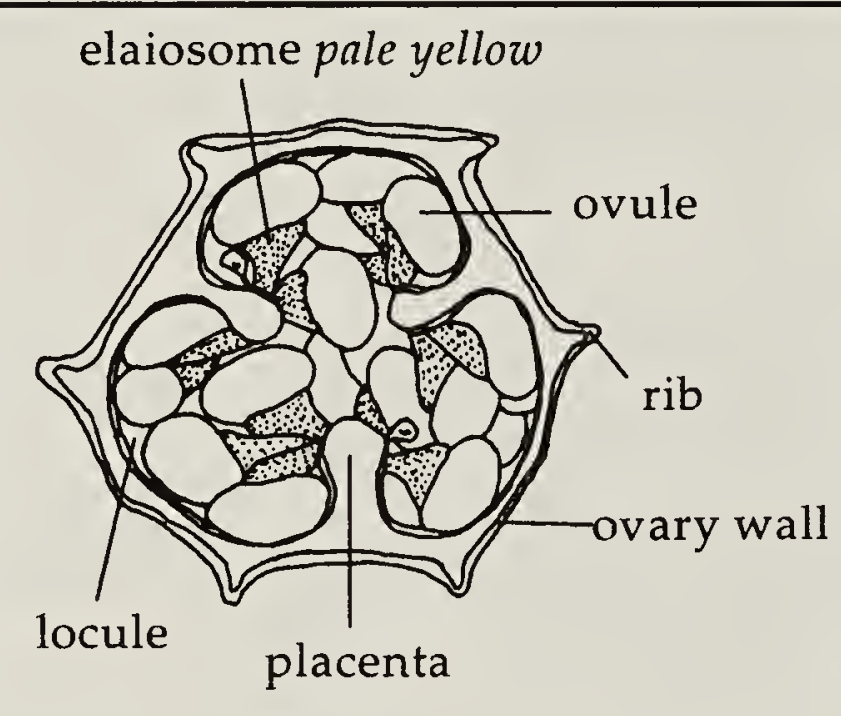

Figure 14a. Cross-section of an ovary, 1 July 2001. Enlarged ovules and elaiosomes almost fill the three locules. $x 3$

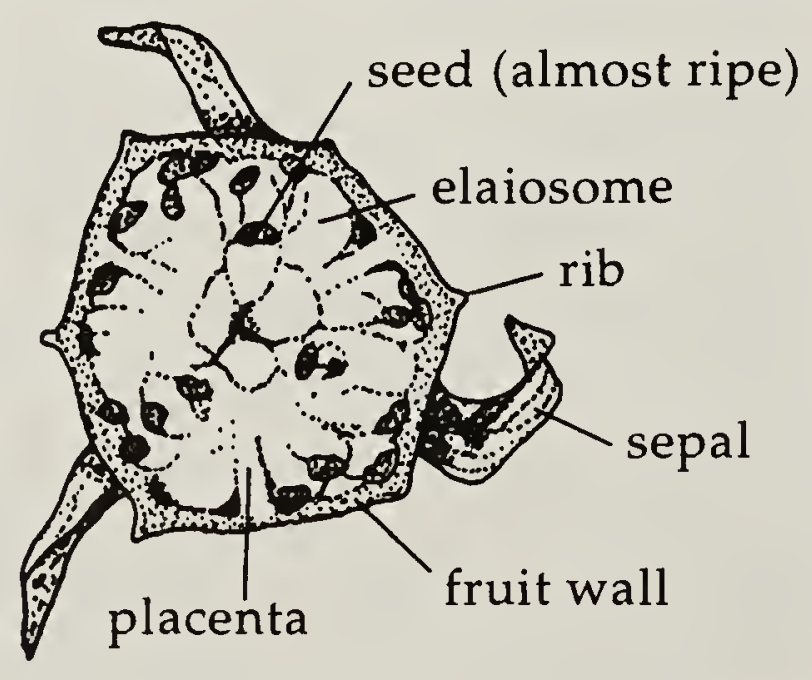

Figure 14b. Cross-section of an almost ripe fruit, 16 August 2001. Pale yellow elaiosomes fill the locules and push many seeds against the locule lining inside the fruit wall. $\times 1$
Changes to the ovary as the fertilized ovules develop into seed are shown in Figs.14a and 14b. In early June 2001, the light yellow ovules of single-flower (SF) plants $(n=21)$ were about $0.5 \mathrm{~mm}$ long. The mean number of ovules per SF ovary was 50 (24-101). For Dwarf White Wakerobin the range for ovules was 13-83 in three populations. ${ }^{31}$
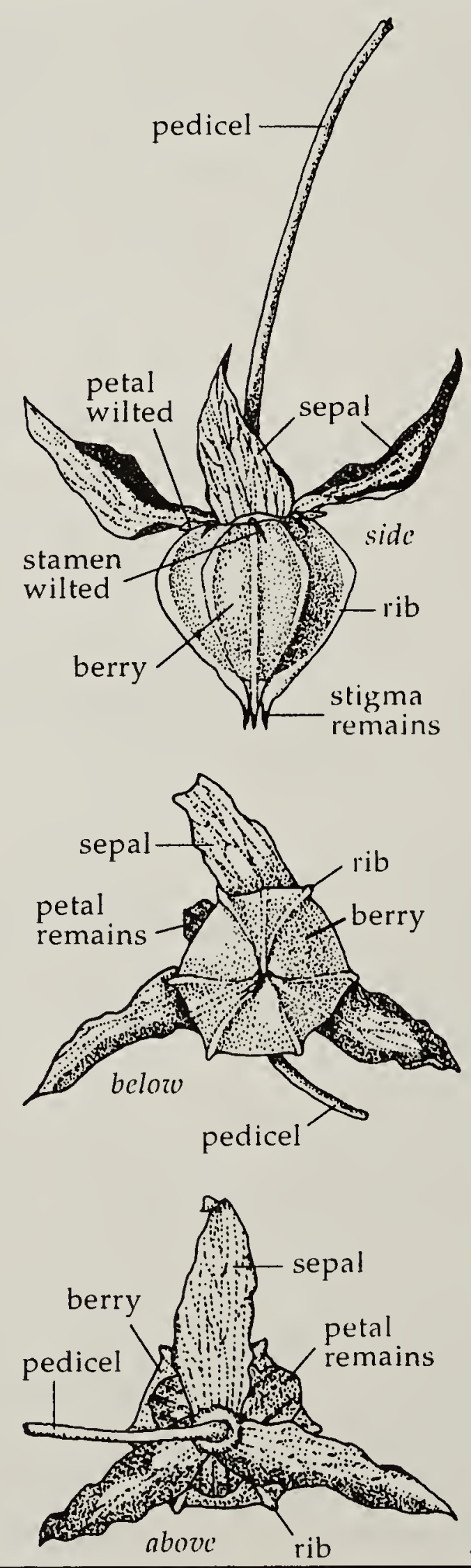

Figure 15. Red ripe fruit from three aspects, 7 August 2001. 
Fruit The fruit is a red, shiny, plump, indehiscent berry, with a faint sweet odour when torn open. It hangs down at the end of the reflexed pedicel (Fig. 15). The six red

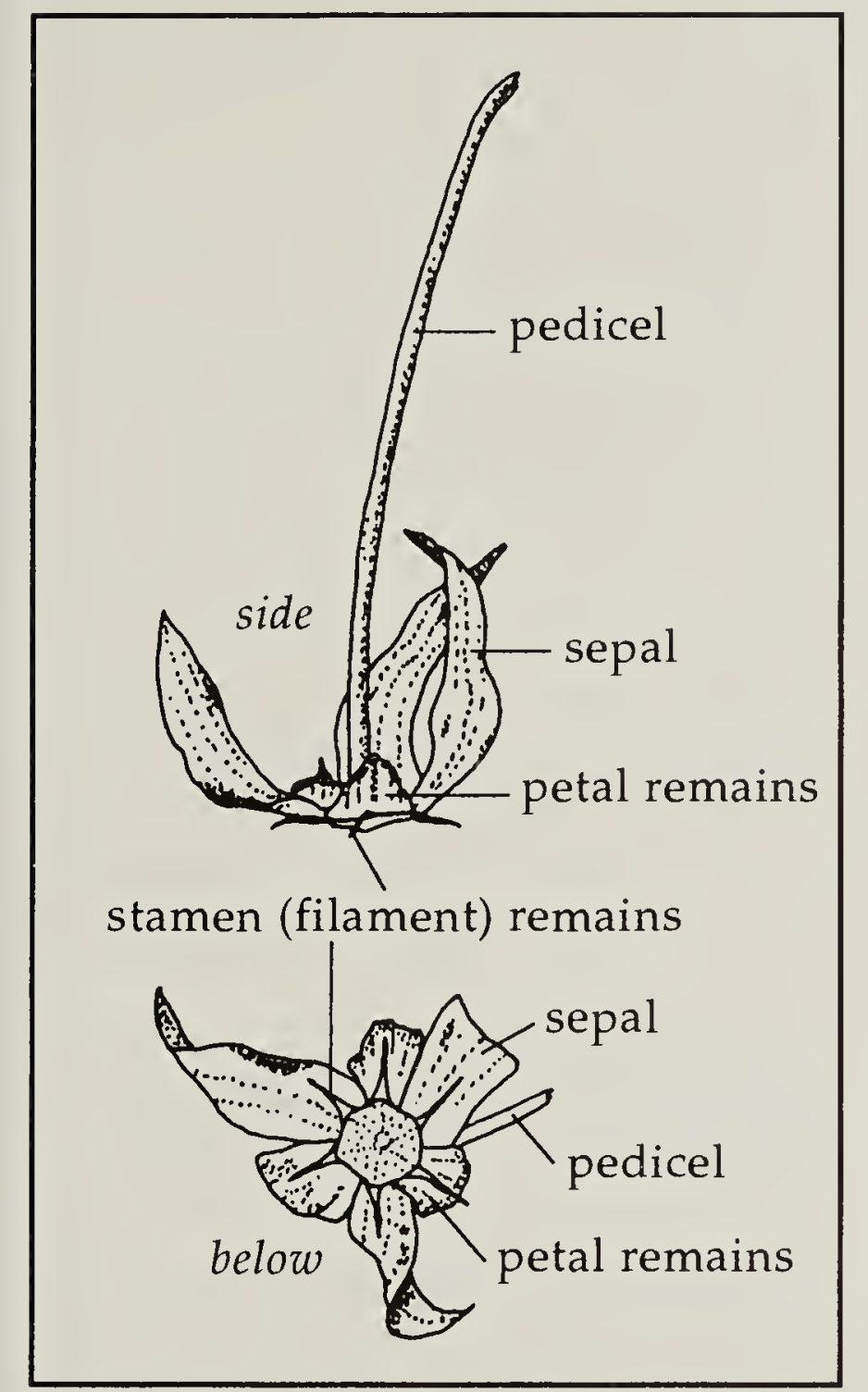

Figure 16. Green sepals and wilted petals remain attached to pedicel after the berry falls to the ground, 23 August 2001. $x 1$

ribs are more obvious on the smaller berries, almost disappearing on large plump ones. Fruit walls are smooth but reticulate (under a microscopic), 1-2 mm thick, fleshy, with a slight transparency which reveals some seeds inside. The locule lining is pink and indented from the seeds. The inside of the berry consists mostly of three placenta and moist, mushy elaiosomes attached to the seeds and placenta. The berry drops from the sepals and pedicel in late August (Fig. 16). It has no basal opening but is soft and the wall quickly disintegrates, or is easily opened by various consumers. Occasionally an almost ripe fruit on the plant displays a 3-5 $\mathrm{mm}$ wide circular opening on its upper side as if a consumer (a slug or a wasp?) is checking on the ripeness of the seeds and elaiosomes. Sizes of regular, single-flower (SF) fruit are presented in Table 2. Extreme (SF) fruit sizes were $24 \mathrm{~mm}$ long and $32 \mathrm{~mm}$ wide. The general trend is larger plants produce larger berries with more seeds. This trend exists for Stinking-benjamin and Large-flower Wakerobin in Vermont. ${ }^{21}$ The fruit of double-flower (DF) plants was slightly larger on average than fruit of singleflower (SF) plants (Table 2).

Seeds The seeds are brown and their shiny, moist coat is finely reticulate (microscopic)

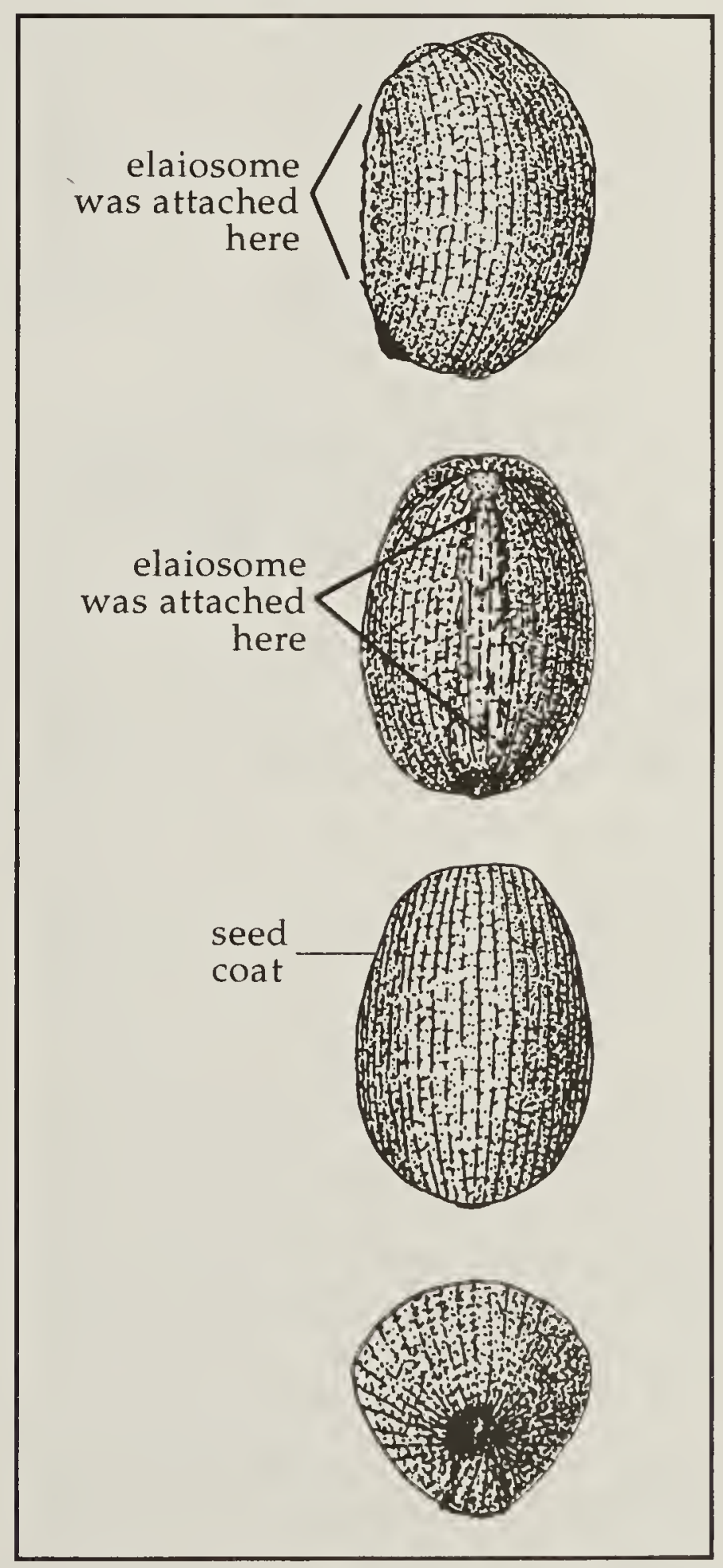

Figure 17. Seed of Trillium cernuum from four aspects on 23 August 2001. From top to bottom: side view, view of hilum region, top view, and end on. 
when first removed from the berry, but dries quickly to a fine rough texture as the reticulation becomes less obvious (Fig. 17). As the summer progresses, the elaiosome (a moist appendage growing from the hilum region of the seed) grows until the seed is ripe. At first the elaiosomes are firm but turn mushy as the fruit becomes fully ripe and shiny red.

For berries from single-flower plants $(n=110)$ the mean number of seeds per berry was 40 , for a seed set of $40 / 50$ ovules $x 100$ $=80 \%$. DFs ( $\mathrm{n}=26$ stems) from 13 rhizomes had a mean of 80 seeds per fruit. The mean number of seeds in the two berries on the long and short stems for each rhizome was 85 and 74 for a difference of 11 seeds. With twice the number of seeds per flower and two flowers per rhizome, DFs have four times as many seeds as SFs.

For Dwarf White Wakerobin in Indiana, the mean number of ovules was 35 compared to 31 seeds for a seed set of $90 \%{ }^{42}$ In two Ohio populations of Dwarf White Wakerobin, the mean number of ovules per pistil was 27 (13-74) and 27 (15-43). Their mean number of seeds and seed set was $18(67 \%)$ and 24 $(89 \%) .{ }^{31}$ A seed set of $58 \%$ and a mean of 28 seeds per fruit was reported for Stinkingbenjamin in Quebec. ${ }^{26}$ In New Hampshire, Stinking-benjamin had a seed set of $65 \%(15$ seeds) for single-flower (SF) plants and 54\% (22 seeds) for double-flower (DF) plants. ${ }^{8}$

Seeds are arranged in a vertical column with 3 to 10 filling a locule from top to bottom. There are from 1-3 horizontal rows on each side of the placenta in each of the three locules. The expanded elaiosomes comprise the bulk of the fruit (Fig. 14b).

With the elaiosome removed, the mean seed length $(\mathrm{n}=83)$ was $2.4 \mathrm{~mm}(2.0-3.0)$, width $1.7 \mathrm{~mm}(1.3-2.0)$, and thickness $1.7 \mathrm{~mm}$ (1.42.0). Without the elaiosome, seeds sink in water. With the elaiosome attached, some seeds sink while others float at the water's surface.
Leaves. On all plants except V1, V2 and $\mathrm{V} 4$, there are three leaves each with a $2-5 \mathrm{~mm}$ long petiole and blades up to $15.5 \mathrm{~cm}$ long (see Table 1). They are curled and imbricate on emergence (Fig. 8). The blades are dull and

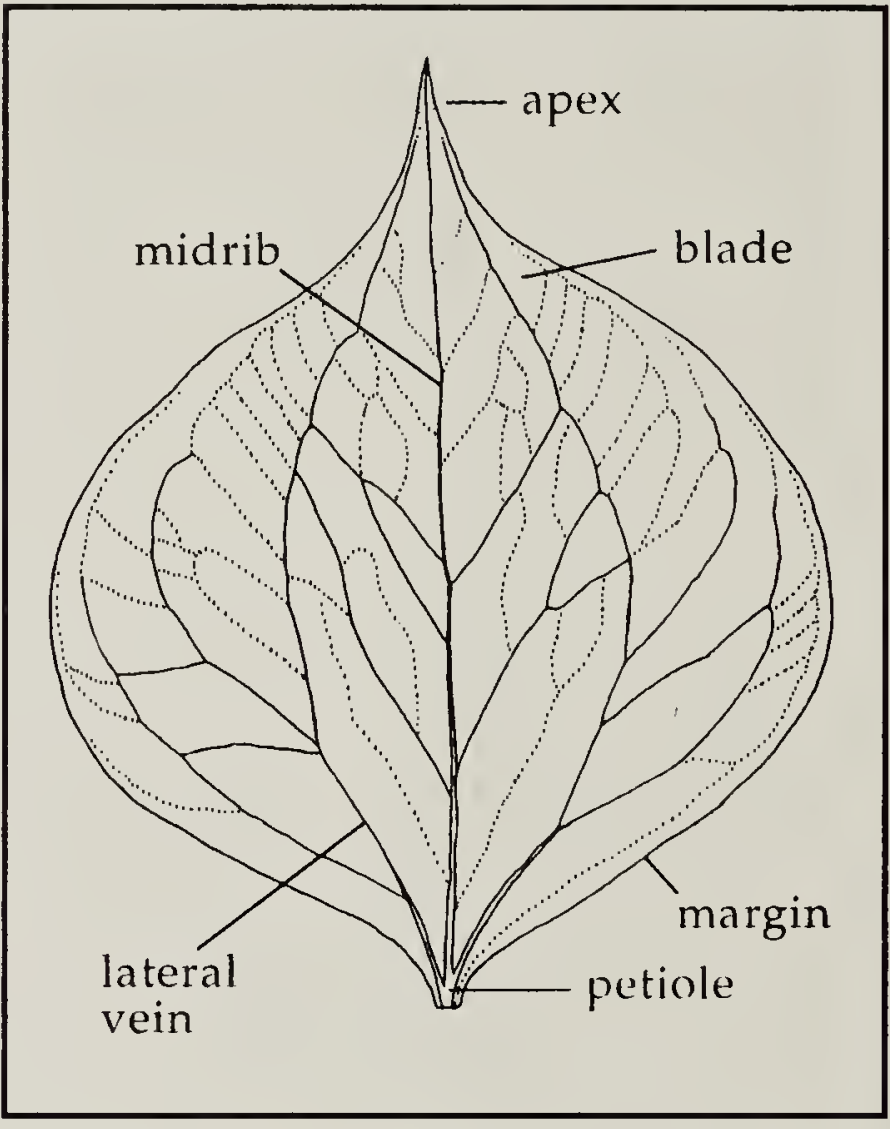

Figure 18. Leaf of Trillium cernuum. $x 0.7$

medium green above with the veins recessed (Fig. 18). The blades are lighter green below and slightly shiny with raised veins. Usually leaves remain mostly green and horizontal well after the fruit has fallen. Sometimes the leaves wilt early and hang to reveal the red ripening fruit in early August. The margins may be undulate, and in wide blades, touching. The three blades on one plant vary slightly in size as was the case for Stinking-benjamin in Ontario where the differences were not significant. ${ }^{37}$ Most leaves are slightly longer than wide, but large leaves are wider than long. A large single-flower T. cernuum plant in 2002 had the largest leaf blade at $18.3 \mathrm{~cm}$ wide and $15.5 \mathrm{~cm}$ long. In Ontario, the leaves may reach $20 \mathrm{~cm}$ in length. ${ }^{35}$

Stems Plants have one or two stems per rhizome. In contrast, Giant Wakerobin, Trillium chloropetalum, may produce up to eight stems per rhizome. ${ }^{5}$ in 31 Stinkingbenjamin in New Hampshire can produce 
up to five stems per rhizome, each with a flower.

Fully developed stems are reddish brown along the lower $2-7 \mathrm{~cm}$, and become green above. The stem is rather weak, solid, roundly triangular in cross section, somewhat crisp, often slightly curved and easily bent. Lapointe found the amount of stored carbohydrate in the stem of Stinkingbenjamin was more than enough to support fruit development in the laboratory over the summer, even with the leaves and rhizome removed. ${ }^{26}$

The previous year's stems (1-4 per plant) are brown, ridged along their length, flat, and lie on the ground extending out from the base of the erect stem like a tan shadow. One or two are usually attached near the top of the rhizome.

Rhizome Each plant has one rhizome. It is tan, cylindrical and 3-6 mm wide $(n=10)$ for young, single-leaf, vegetative (V1) plants and becomes dark brown near the distant decomposing end in older plants. The inside of a rhizome is solid, pale yellow and uniform in texture. Rhizomes range from 3-46 mm long by 3-19 mm wide, increasing in size with age. They are usually widest at the apex (especially rhizomes with a crown bud in autumn) and tapered toward the base. The mean depth of rhizomes of vegetative and flowering (V1, V3, SF, and DF, n=63) plants was $5 \mathrm{~cm}$ below the soil (0.5-8.6), measured from the soil's surface to the rhizome's apex.

Rhizomes are often slightly bent away from the vertical of the stem's axis. Young vegetative (V1) plants have a straight, vertical rhizome. Some older flowering plants have a rhizome with a $90^{\circ}$ bend somewhere along its length making the distal portion horizontal (Fig. 19).

Roots and crown buds arise from rhizomes, but no lateral buds were observed. Stem scars and membranous rings on the

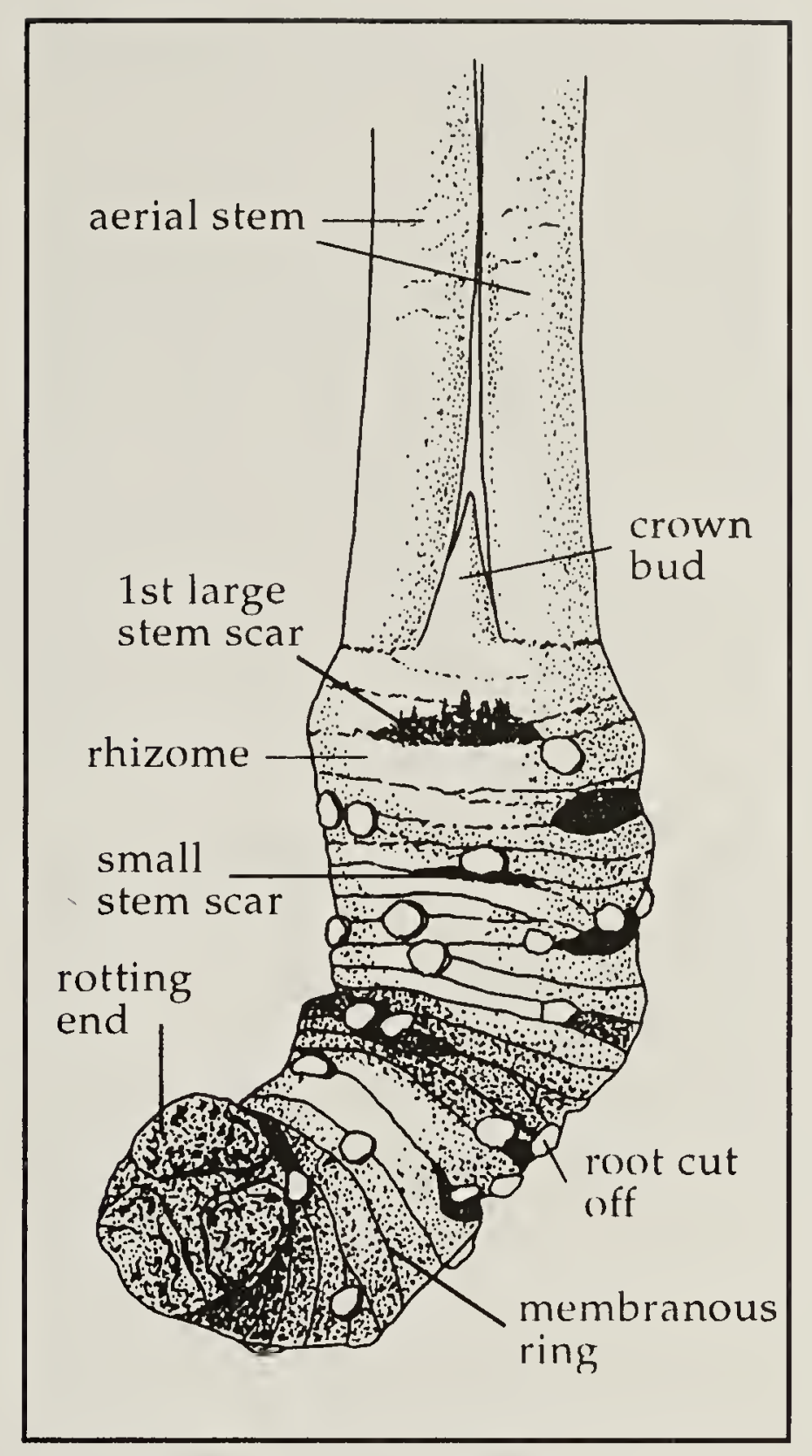

Figure 19. Rhizome of a DF plant showing its bend and other features, 18 June 2001. $x 2$

rhizome surface are used to age plants and are described in the section on ageing below.

$\underline{\text { Roots }}$ Roots range from $0.5-12 \mathrm{~cm}$ long by $0.4-2.5 \mathrm{~mm}$ thick. They vary in number from few on a young vegetative (V1) plant up to 53 on a large double-flower plant where they obscure the shape and size of the rhizome. New roots emerge near the top of the rhizome. Roots are light tan, smooth and mostly less than $2 \mathrm{~cm}$ long. Most roots are unbranched but some develop up to a dozen branches which in turn may rebranch.

Older roots have a wrinkled portion (contractile?) starting at the rhizome and extending out to about $4 \mathrm{~cm}$ in length (visible in Fig. 8). The distal part of these roots is 
smooth. For Dwarf White Wakerobin the contractile portion was about $1 \mathrm{~cm}$ long nearest the rhizome. ${ }^{31}$

Crown buds Crown buds are buds of future plant growth sitting beneath the surface. Their membranous covers, which

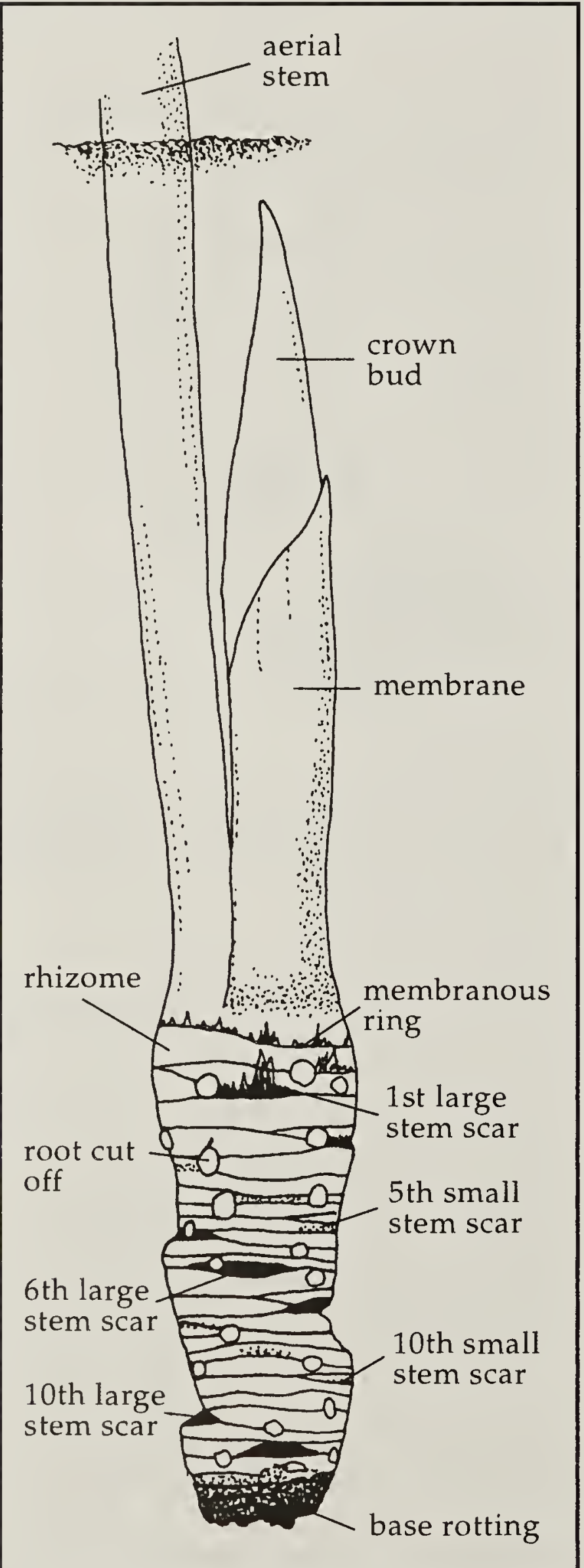

Figure 19a. Rhizome of a SF plant with stem scars in a spiral and a large crown bud, 21 September 2002. are white, smooth, erect and pointed, are underground at the base of the current stem (Fig. 19a). They begin to expand from a rhizome's apex as the berry ripens, and continue to develop into September.

On V1 plants the crown bud is narrow, with a stem and usually one leaf inside indicating that the plant will again be a V1 plant the following year. For example, on 26 August 2001, a V1 plant $5.7 \mathrm{~cm}$ tall had a single aerial leaf blade $3.2 \mathrm{~cm}$ long by $2.6 \mathrm{~cm}$ wide. The new shoot inside the crown bud consisted of a $2 \mathrm{~mm}$ long, white erect stem and an erect, curled, pale yellow leaf blade $4.5 \mathrm{~mm}$ long by about $4 \mathrm{~mm}$ wide when unrolled and flattened.

On V3 plants the crown bud may contain a young shoot and a smaller crown bud with pale yellow shoot primordium about $1 \mathrm{~mm}$

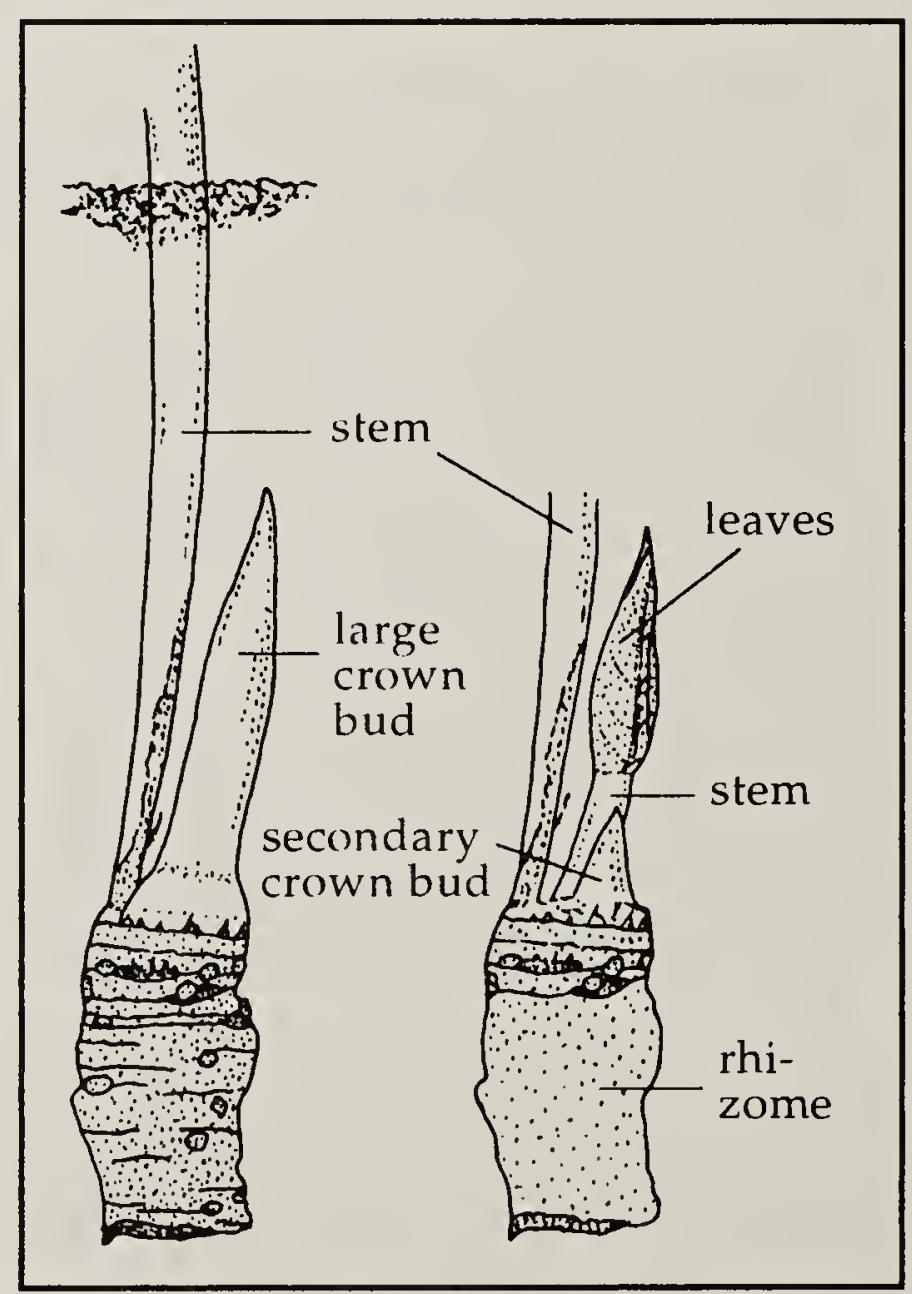

Figure 20. Crown bud of a V3 plant 31.5 cm tall, 30 August 2001. Crown bud membranes are intact (left) and removed (right) to reveal the new shoot (next year's plant) along with its crown bud at the base of the stem. Inside the leaves is a young flower with only three stamens. 
long. A V3 plant $31.5 \mathrm{~cm}$ tall on 30 August 2001 had a crown bud $31 \mathrm{~mm}$ long. Inside was a shoot with three leaves that were 16 $\mathrm{mm}$ long and a flower with three stamens about $5 \mathrm{~mm}$ long and a pistil about $4 \mathrm{~mm}$ long (Fig. 20). This shoot would have emerged as a single-flower (SF) plant in 2002. Next to the shoot was a small, white secondary crown bud about $6 \mathrm{~mm}$ long. Always shorter than the stem of the main shoot, this bud will develop into a plant two years hence. A flower is usually absent in the crown bud of young, short V3 plants indicating they will repeat as a V3 plant the next year.

Large single-flower (SF) plants have crown buds which remind me of a set of stacking Chinese boxes. Careful dissection revealed at least three crown buds, each reduced in size. Staining may reveal more as tiny buds are clustered inside the $4-8 \mathrm{~mm}$ tall secondary crown bud adjacent to the stem of the main shoot. The secondary crown bud of the T. cernuum is present in the fall, overwinters and maintains its size (about $5 \mathrm{~mm}$ long) and position in the spring as the new aerial shoot emerges from the large crown bud. Beneath the collapsed membranes of the large active bud is the new crown bud. Bud formation is a continuous process atop the rhizome. In Trillium kamtschaticum, primordia form 3-10 years prior to aerial growth. ${ }^{40}$ in 31

The crown bud of a double-flower (DF) plant is located between the two current stems (Fig. 21). It may reach $5.0 \mathrm{~cm}$ in length with the pointed tip 5-10 mm above ground in September. Within the bud there are usually two large new shoots, indicating it will be a DF plant again next year (Figs. 21 21c). In five DFs examined, one crown bud had only one shoot, indicating double-flower (DF) plants can revert to a single-flower (SF) plant. How far in advance is this decision made by the Whip-poor-will-flower?

\section{Ageing}

The parts of the rhizome used to age trillium plants are stem scars and membranous rings.
Stem scars develop where the base of a stem breaks free from the outer surface of a rhizome. Stem scars are arranged in a spiral along the length of the rhizome (Fig. 22), a fact not mentioned in other Trillium papers. The spiral pattern may travel clockwise or counter-clockwise. A close look reveals two spirals of stem scars per rhizome, one of large scars and one of smaller ones, both visible in Fig. 22. Some very young vegetative (V1) plants have rhizomes without large scars but most have a least one. Young short V3 plant rhizomes and all older, large rhizomes have large scars.

Large scars are dark brown, shelf-like, crescent-shaped structures 1-6 mm long and up to $2.5 \mathrm{~mm}$ wide or deep. Five of them, about $72^{\circ}$ apart, form a circle when the rhizome is viewed from above. The most recent large scar is near the top of the rhizome and usually has dark, erect veiny fragments remaining from the previous year's stem.

The second spiral of stem scars is less obvious. These scars are smaller and only slightly recessed as can be seen in Figs. 19 and 19a. The top or first scar is on the opposite side of the rhizome from the base of the growing stem and often indistinct. The lower scars are more apparent, especially when viewed through a dissecting microscope. My hypothesis is that each small scar in the secondary spiral is formed by the degeneration of a small crown bud and shoot inside the main large crown bud. A count of the smaller scars results in a number equal, or almost so, to the number of large scars, depending on the position of the lowermost scar in relation to the angled, decaying base of the rhizome.

Membranous rings are thin, dark brown horizontal lines around the outside of the rhizome (Figs. 19 and 19a). Generally about $1 \mathrm{~mm}$ apart, they range from $0.2-2.6 \mathrm{~mm}$ apart and are widely separated at the top of the rhizome. Membranous rings are formed from the basal remains of the white membranous covers of the main crown bud. 


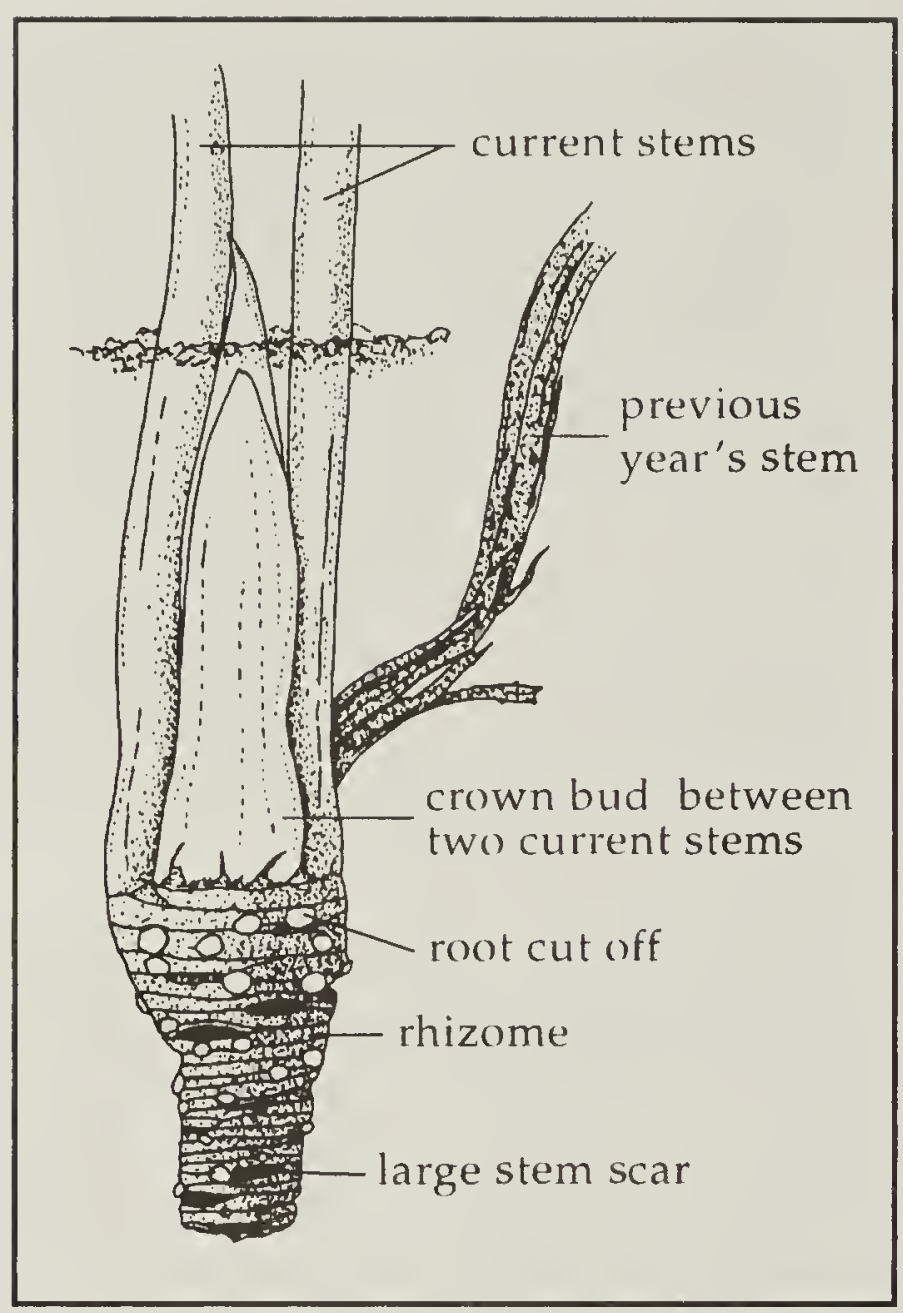

Figure 21. The crown bud (with membranes intact) of a DF plant, 13 September 2001.

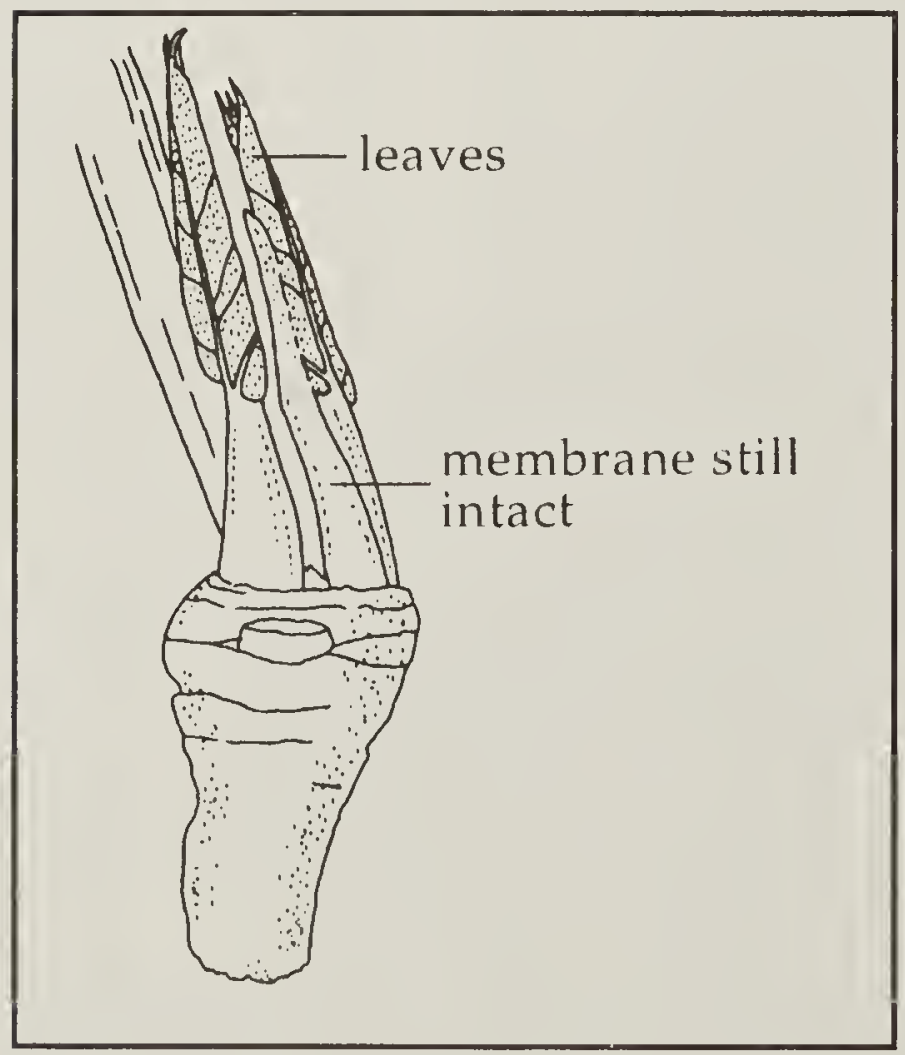

Figure 21b. Secondary crown bud membranes removed to show a second large, young shoot inside (next year's DF plant). $x 0.8$ current stem

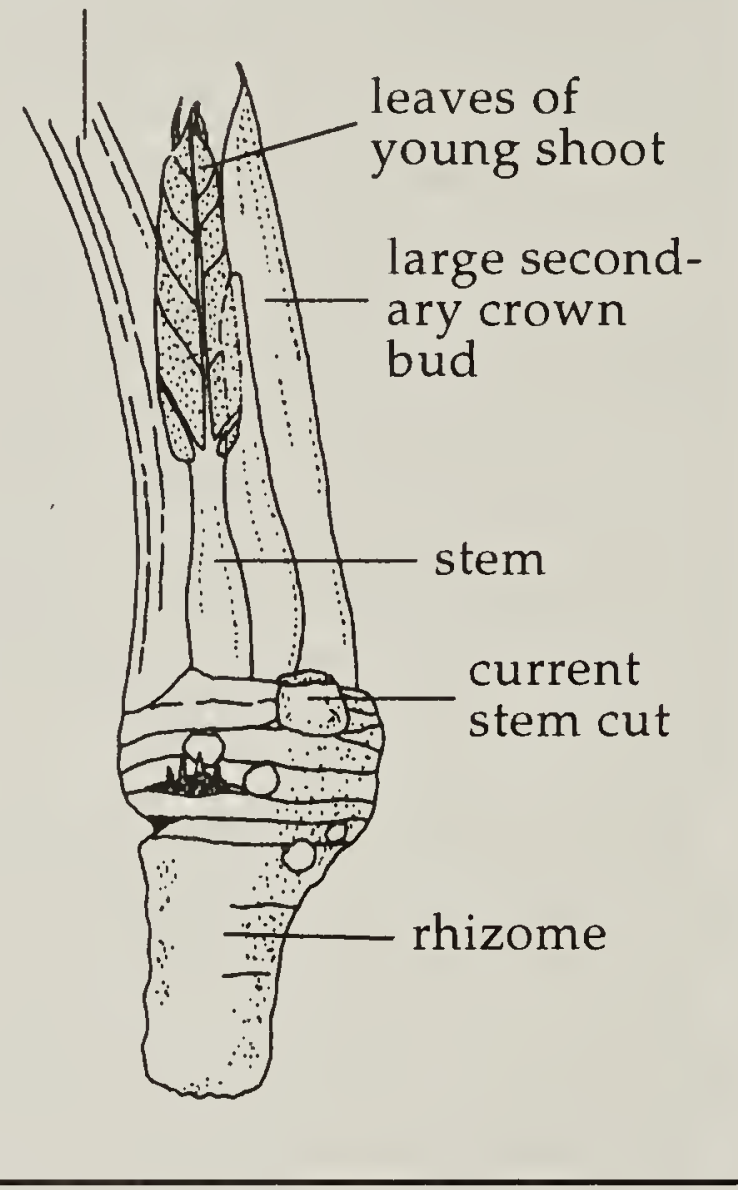

Figure 21a. Crown bud with membrane covers removed, revealing the large secondary crown bud. $x 0.8$

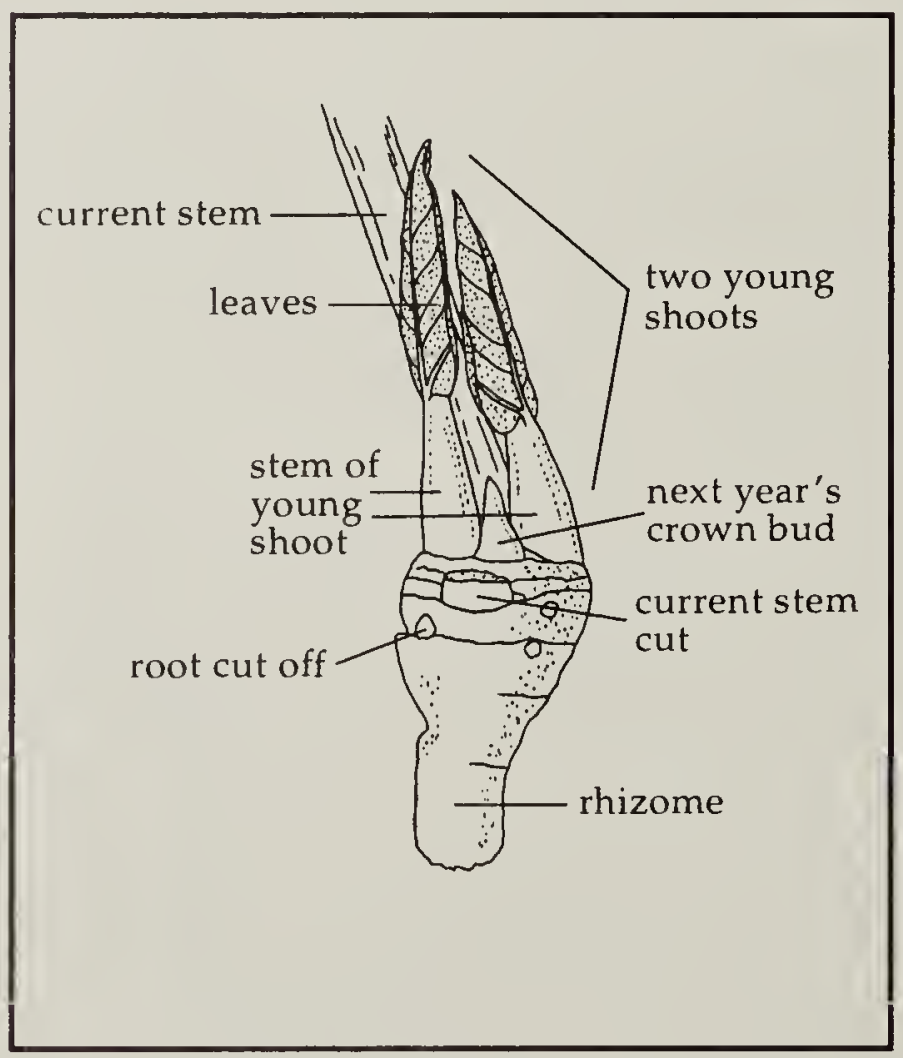

Figure 21c. Renaining membrane removed to reveal the small crown bud between the two new young shoots' stems. 


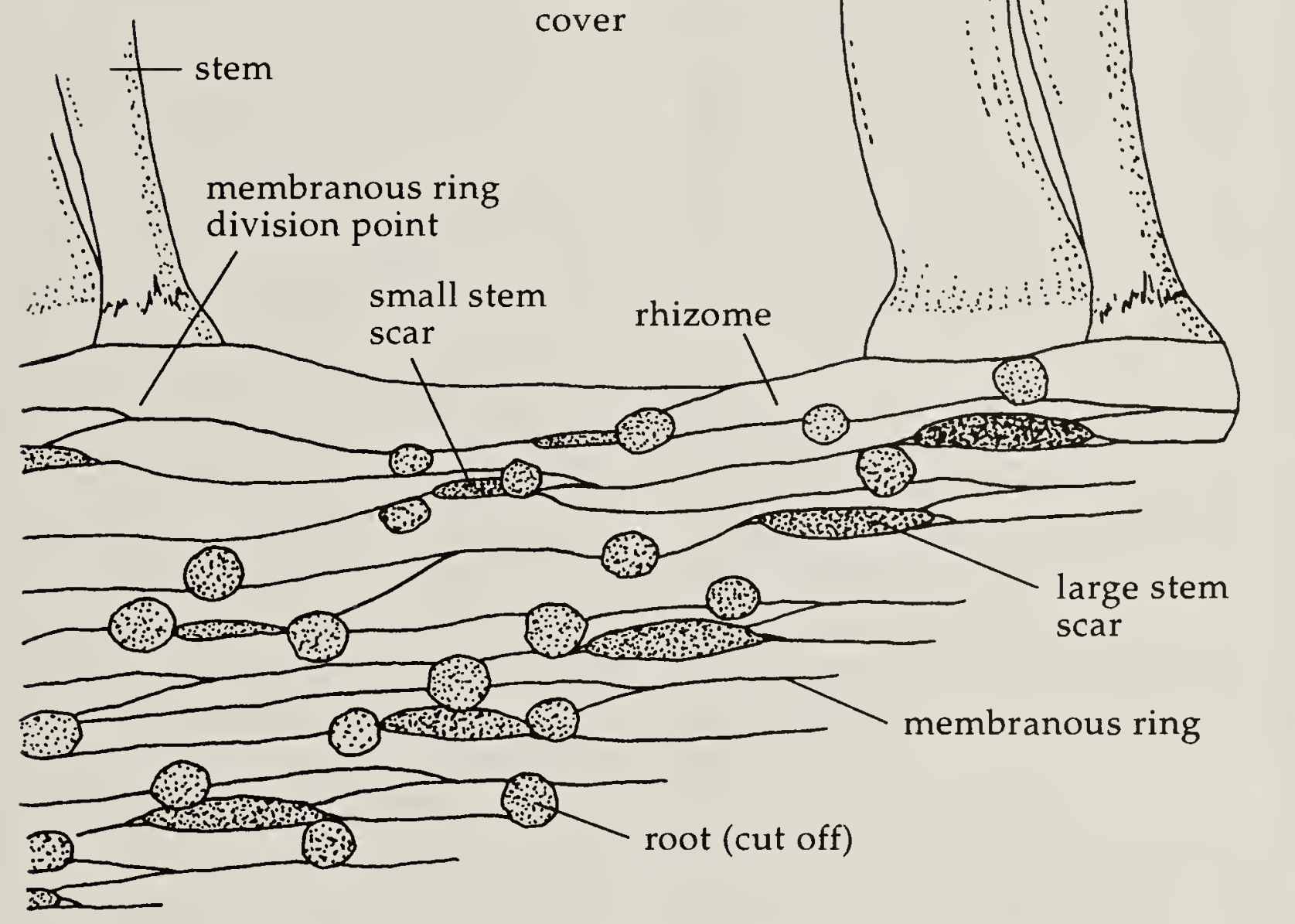

Figure 22. Diagrammatic drawing of a flattened rhizome of a single-flower plant (SF), 6 September 2001, showing the two spirals of stem scars, the membrane rings, stem base and crown bud. $x 3$

Within the membranous cover is the large shoot (next year's plant) and at its base a small, white, secondary crown bud with its own set of membranous covers (Fig. 20). There are two membranous rings between the top large stem scars (Fig. 22). The upper ring branches in two just before it enters a scar with the upper branch passing over the top of the scar and the other branch entering the scar. Two rings then continue to the next scar. Dividing the total number of rings on a rhizome by two generally results in a number equal to the number of stem scars in each spiral on a rhizome. On young rhizomes of V1 plants without stem scars, the rings form a continuous circle around the rhizome. For example, the vertical rhizome of one $\mathrm{V} 1$ plant was $10 \mathrm{~mm}$ long with no stem scars visible but 14 membranous rings gave it an age of seven years, eight if you include the first year of growth when no leaf is produced, or nine if you include the current stem. 
There are three methods, described in the literature, for ageing Trillium species using rhizome features. The first method is to count the total number of dark, thin, membranous rings on the rhizome and assume one ring equals one year's growth., ${ }^{8} 17$ This method, I believe, as do others, overestimates the actual age of the plant. $^{31}$

The second method, a variation of the first, is to count the number of membranous rings and divide that number by three. Three was used since this is the number of membranous covers of the crown bud surrounding the young Dwarf White Wakerobin shoot inside. ${ }^{31}$ Another researcher counted the membranous rings but divided their number by two since he found two membranous covers on the crown bud of Blue Ridge Wakerobin, Trillium stamineum. Plants with one flower, aged in this manner, were 7-17 years old. ${ }^{41}$

The third method, and the most accurate, is to count the number of large stem scars on the rhizome. This method was used to estimate the minimum age for Dwarf White Wakerobin, assuming one stem scar is produced each year until the rhizome is large enough to generate two or more stems in one year. ${ }^{31}$

All three ageing methods have a shortfall because, as the end of the rhizome decomposes, both rings and scars are lost to the soil. Thus these methods can only provide a minimum age. The rhizome begins to decompose quite early in a Whip-poorwill-flower's life. Seven of the ten one-leaf vegetative (V1) plants excavated in July 2002 in Winnipeg had a decaying rhizome. All ten V3 plants had a rotting base on their rhizomes. All flowering plants, ten singleflower (SF) and ten double- flower (DF), exhibited a decomposing rhizome.

To make the estimates used in this study, I ignored the number of membranous covers around the crown bud. Instead I counted the number of membranous rings between large scars at the top of the rhizome and came up with two. Counting the number of complete membranous rings is problematic since the rings cannot be traced in a complete circle around a rhizome with large stem scars (as shown in Fig. 22), a fact not mentioned by other researchers. However, once counted, division by two gives a number equal or close to the number of stem scars in each spiral and this was taken to be the age of the plant. The largest $T$. cernuum plant had 32 rings and 16 scars or years of age. I would estimate T. cernuum plants, especially doubles, are probably 20-30 years of age.

I used the ages determined in this way to see if stem length and leaf blade width correlate with plant age. In July and early August 2002, before the fruit was fully ripe, I dug out Whip-poor-will-flower rhizomes from ten plants in each of four categories: V1, V3, SF and DF. The number of large stem scars was plotted against stem length (Fig. 23) and leaf blade width (Fig. 24). Although in general, taller plants have wider leaves and are older as the upward trends of the two graphs indicate, neither the stem length nor the blade width were accurate indicators of plant age. A stem about $25 \mathrm{~cm}$ tall could have a rhizome with 7-13 large stem scars and a leaf blade about $10 \mathrm{~cm}$ wide could have a rhizome with 7-15 large stem scars. A rhizome with 7 large stem scars may appear as a V1, V3, SF or even a DF plant with a height ranging from $7-26.2 \mathrm{~cm}$. An older plant with 13 large stem scars might surface as a V3, SF, or a DF plant 25.5- 46 $\mathrm{cm}$ tall. A similar situation is found with the leaf width.

It was perplexing to discover that some vegetative, one-leaf (V1) plants had a rhizome full of large stem scars while others of about the same length had none or only a few large scars. The lack of stem scars on some young rhizomes could indicate the lack of an aerial stem for one or more years. In Large-flower Wakerobin, some rhizomes do not produce aerial parts each year, or they produce a large vegetative plant. This is 


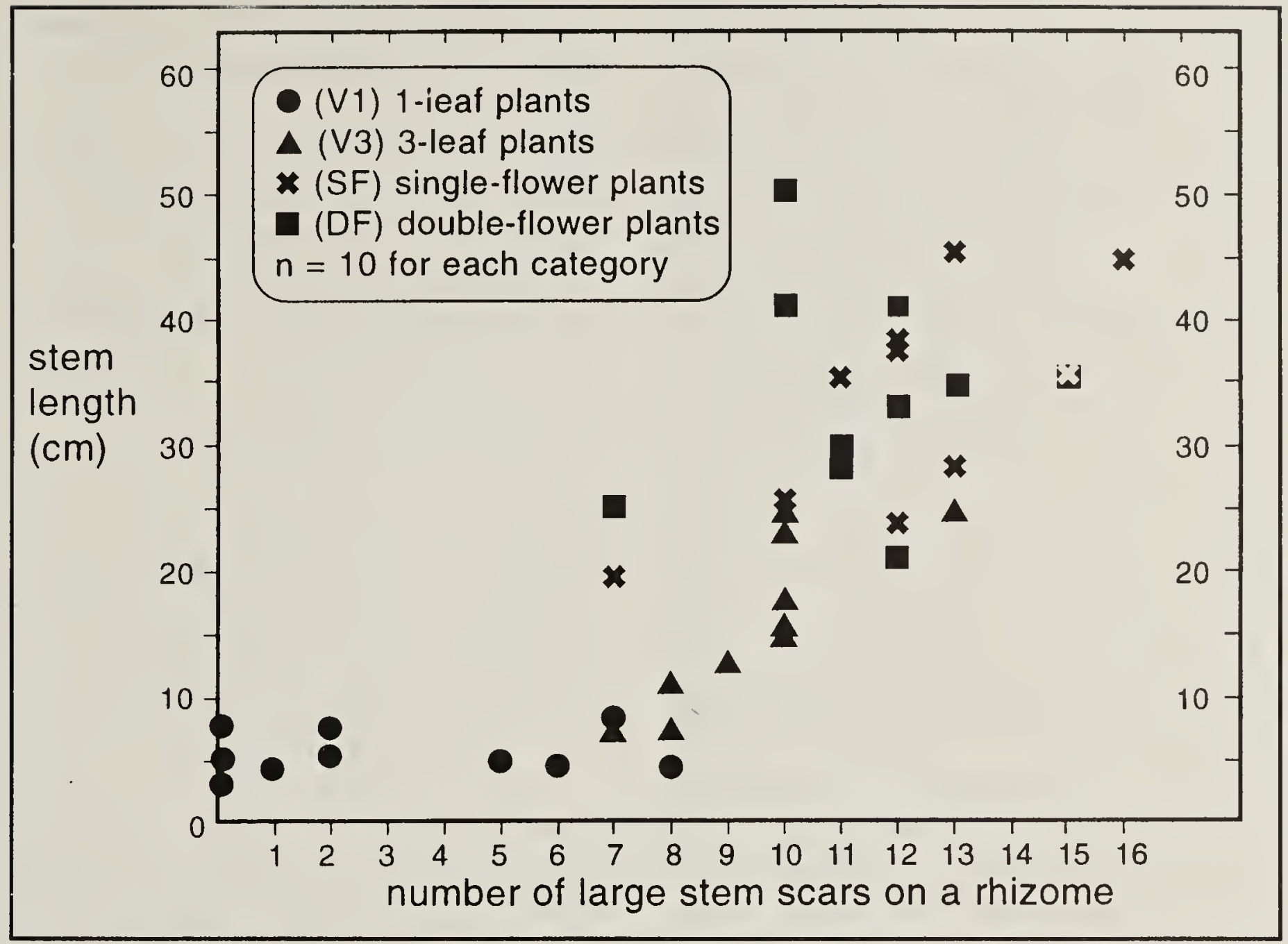

Figure 23. Relationship between stem length and number of large stem scars on rhizomes in four categories of plants of Trillium cernuum.

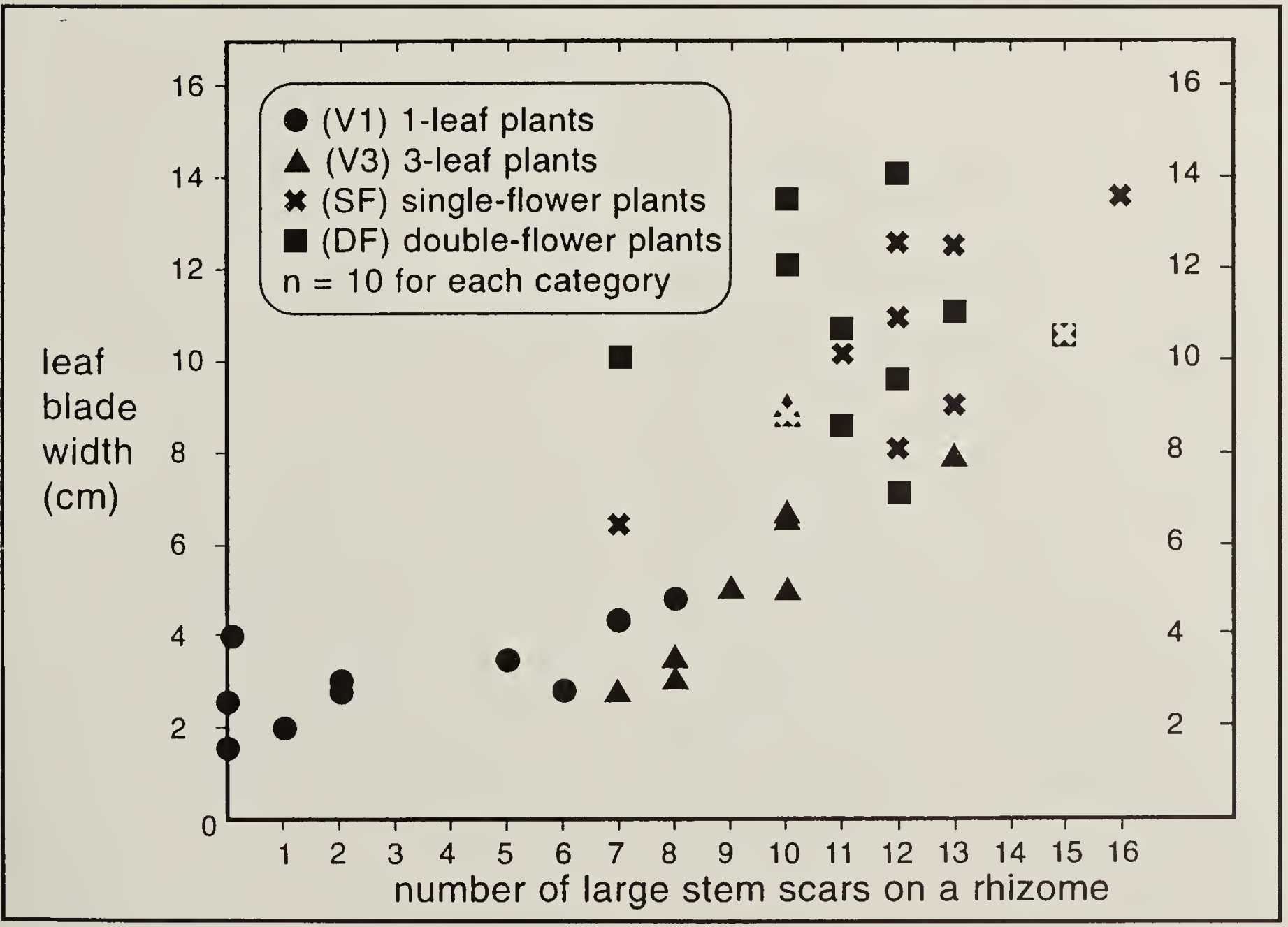

Figure 24. Relationship between leaf blade width and number of large stem scars on rhizomes in four categories of plants of Trillium cernuum. 
probably due to poor storage performance by a plant the previous year. ${ }^{17}$ When no aerial stems are produced, several of these early years are lost in the counting of scars on older rhizomes due to their lack of early stem scar production. Also, the early scars are the first to be lost as the end of the growing rhizome disintegrates in the soil. More attention to rhizomes in the Trillium species is necessary if we are to begin to understand growth adjustments of this variable, longlived perennial.

\section{Plant associates}

In my study, the mean distance from one $T$. cernuum plant to the next $T$. cernuum (all categories, $n=159)$ was $25.7 \mathrm{~cm}(1.0-92.4)$. For single-flower (SF) plants $(n=117)$ the nearest $T$. cernuum neighbour was a mean of $31.0 \mathrm{~cm}$ away. The mean distance and range from the nearest SF are, by category: V1 $(7 \%)$ at a mean distance of $45.2 \mathrm{~cm}$ (11.1$195.0)$ from a SF plant; V3 $(69 \%)$ at $29.2 \mathrm{~cm}$ (0.2-160.0); $\mathrm{SF}(23 \%)$ at $32.3 \mathrm{~cm}(5.5-133.5)$, and DF $(1 \%)$ at $31.7 \mathrm{~cm}$. The mean distance from a $T$. cernuum to a non-trillium plant $(n=159)$ within the quadrats was $13.0 \mathrm{~cm}$ $(1.0-57.5)$.

Twelve species of non-trillium plants were identified in the quadrats. In order of decreasing abundance they are Starry False Solomon's-seal, Maianthemum stellatum 58 (37\%); European Buckthorn, Rhamnus cathartica 56 (36\%); Choke cherry, Prunus virginiana 18 (12\%); False Lily-of-thevalley, Maianthemum canadense 8 (5\%); Thicket-creeper, Parthenocissus vitacea 4 (2.5\%); Green Ash (dead), Fraxinus pennsylvanica 3 (2\%); Swamp Red Currant, Ribes triste 2 (1.3\%); King Solomon's Seal, Polygonatum biflorum 2 (1.3\%); Wild Sarsaparila, Aralia nudicaulis 1 (0.6\%); Western Poison Ivy, Toxicodendron rydbergii 1 (0.6\%); American Elm, Ulmus americana 1 (0.6\%): Ash-leaf Maple, Acer negundo 1 (0.6\%); and an unknown deciduous shrub $1(0.6 \%)$. The first three species account for $85 \%$ of the close encounters of an alternate kind for $T$. cernuum in the quadrats.
In the eight quadrats the shrub European Buckthorn had a mean distance from a $T$. cernuum of $10.3 \mathrm{~cm}(1-33.3)$. The mean buckthorn height was $102 \mathrm{~cm}$ (4 to about $600)$. However, when shrubs taller than $1 \mathrm{~m}$ are excluded $(n=10)$, the mean height is 13.1 $\mathrm{cm}$ (4-50). During this study it was apparent that hundreds of small European Buckthorn shrubs were growing in this forest though the taller shrubs were usually dead due to a buckthorn eradication program.

\section{Predation by deer}

As one of the few sources of fresh green growth on the forest floor in May and early

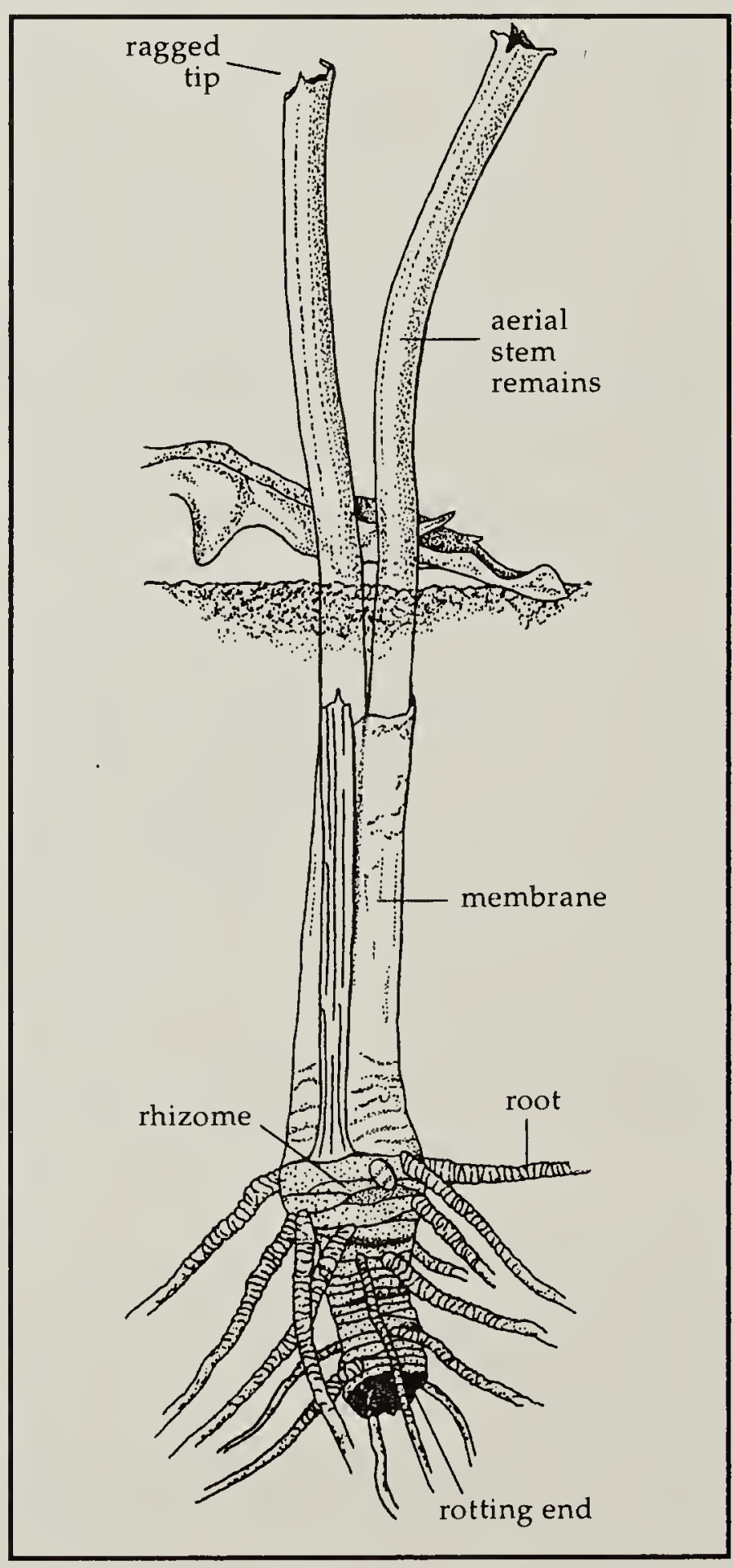

Figure 25. A double-stem Trillium cernuum browsed by a White-tailed Deer, 16 May 2001. 
June, T. cernuum is an attractive food for White-tailed Deer which eat the upper plant leaving about half or more of the lower stem with a ragged tip (Fig. 25). Browsing by deer (not observed) occurs mainly in mid- to late May as the plants are about to flower, or are flowering. Starry False Solomon's-seal are also readily eaten by deer in spring.

T. cernuum stems that remain after browsing $(n=89)$ had a mean length of 18.0 $\mathrm{cm}$ (4.6-37.5) with a mean basal width of $5.0 \mathrm{~mm}(2.5-7.7)$. These plants were outside the quadrats and mostly in the central western part of the population. I would estimate $100-200$ stems $(<1 \%$ of the total population) were consumed by deer in the spring each year.

In Illinois, White-tailed Deer seemed to preferentially browse taller plants of Largeflower Wakerobin. Annual browsing of the same plants over several years causes a decline in their height and reproductive ability since the leaves and flowers are consumed each year early in the spring and no regrowth takes place. ${ }^{2}$

In the Winnipeg population, the remaining browsed stem height for DFs $(n=46)$ was 17.3 $\mathrm{cm}$ (5.1-37.5) compared to $33.9 \mathrm{~cm}(23.0-46.6)$ on mature $(n=128)$ unbrowsed doubles elsewhere. The $17.3 \mathrm{~cm}$ height is biased toward the low end since the plants were measured from 13-24 May 2001. Browsing by deer at this time was on plants not fully grown.

Of the 89 browsed stems I measured, 46 stems (52\%) belonged to 23 doubles (DV and DF). Seventeen (74\%) of these 23 doubles had both stems eaten; only 6 (26\%) of the doubles had one stem eaten with the uneaten stem bearing a flower. In my selective search for browsed plants, a bias was due to the ease of visually locating the thick remains of an eaten double compared to a single thin vegetative plant's browsed stem.

For browsed plants $(n=66)$, the mean distance to the nearest $T$. cernuum was 11.6 $\mathrm{cm}(2.0-30.6)$. This distance is less than half the mean distance for the categories recorded within quadrats (where no doubles were present) of $25.7 \mathrm{~cm}(1.0-92.4)$ indicating deer browse where the plants are close together. Three plant categories accounted for $96 \%$ of the nearest neighbour to browsed stems: a single browsed stem $(n=30,44 \%)$ at a mean distance of $11.6 \mathrm{~cm}$; vegetative (V3) plants $(\mathrm{n}=22,32 \%)$ at a mean distance of $15.0 \mathrm{~cm}$; and doubles $(n=14,20 \%)$ at a mean distance of $6.1 \mathrm{~cm}$. Since about half of the browsed Whip-poorwill-flowers were doubles and the closest neighbours were also doubles, the data suggest deer tend to browse where the large doubles grow.

Unbrowsed doubles (DF and DV) located systematically had a nearest $T$. cernuum neighbour mean distance of $25.4 \mathrm{~cm}(\mathrm{n}=33)$ which is close to the mean distance of $25.7 \mathrm{~cm}$ for the quadrat plants where no doubles were present. As well, $9(27 \%)$ of unbrowsed doubles had another double (5 DF and 4 DV) as its nearest neighbour and their mean distance was only $16.5 \mathrm{~cm}$. By comparison, single-stem vegetative (V3) plants were a mean of $29.4 \mathrm{~cm}$ $(n=24,73 \%)$ from the doubles, which is about twice that recorded for the browsed doubles above.

\section{Other herbivores}

On 13 May 2001, I watched a Cottontail Rabbit eat a $T$. cernuum (not reported previously as a predator of trilliums). The rabbit nipped the stem off at its base and proceeded to eat the stem toward the leaves and flower bud. One rabbit was seen occasionally throughout the summer in the trillium population. Near its resting place under shrubbery in 2002, most of the trillium plants for about a $5 \mathrm{~m}$ radius were noticeably absent compared to the previous year indicating heavy predation in that area. No estimate of the number of $T$. cernum eaten by the rabbit was possible since the stem bases are not readily visible. The cottontail's range, like that of White-tailed Deer, overlaps much of the range of the Whip-poor-will-flower. ${ }^{12}$

On 18 August 2002, as I was measuring 
fruit sizes of double-flower (DF) plants, two ripe fruit were on the ground. About onethird of one berry was eaten and seeds were scattered around it. The predation was likely by a small mammal. Since I never observed mice in the open woods, I suspect American Red Squirrels or Eastern Chipmunks were eating the elaiosomes. The scattered seeds had only parts of their elaiosomes still attached. No ants attended the exposed berry. In Indiana, rodents (unspecified spp.) took fewer than $5 \%$ of Dwarf White Wakerobin fruit. $^{42}$

On 25 August 2002, twelve ripe fruit still attached to SF plants were observed (through binoculars) from a distance of 1 to $7 \mathrm{~m}$ away, for an hour in the late sunny morning. No insect or mammalian predation was recorded. Both an American Red Squirrel and an Eastern Chipmunk were in the area but appeared not to notice the ripe berries. A week later all the fruit had fallen from the plants. No berries were found on the floor near the plants or elsewhere. Perhaps after the fruit falls it is discovered and carried away by squirrels and chipmunks.

\section{Invertebrates}

T. cernuum pistils were almost without insect damage. Only one double-flower (DF) plant had both pistils chewed. None of the ovaries or fruit I opened had larvae inside. For Stinking-benjamin, larvae of two species of Clepsis moths often infested the flowers in New Hampshire. ${ }^{8}$

A grey slug (Arion spp., Family Arionidae) about $2 \mathrm{~cm}$ long was observed (probably eating the elaiosomes) half inside one ripe fallen $T$. cernuum berry (Fig. 26) on 17 August 2001 and again on 25 August 2002. Slime trails were occasionally noticed on fruit still attached to an erect plant. Millipedes, too young to identify, also feed inside ripe decaying berries on the ground. In northern California, $20 \mathrm{~cm}$ long Banana Slugs, Ariolimax columbianus, and snails, Vespericola megasoma, feed on elaiosomes of T. ovatum, Western Wakerobin. ${ }^{28}$

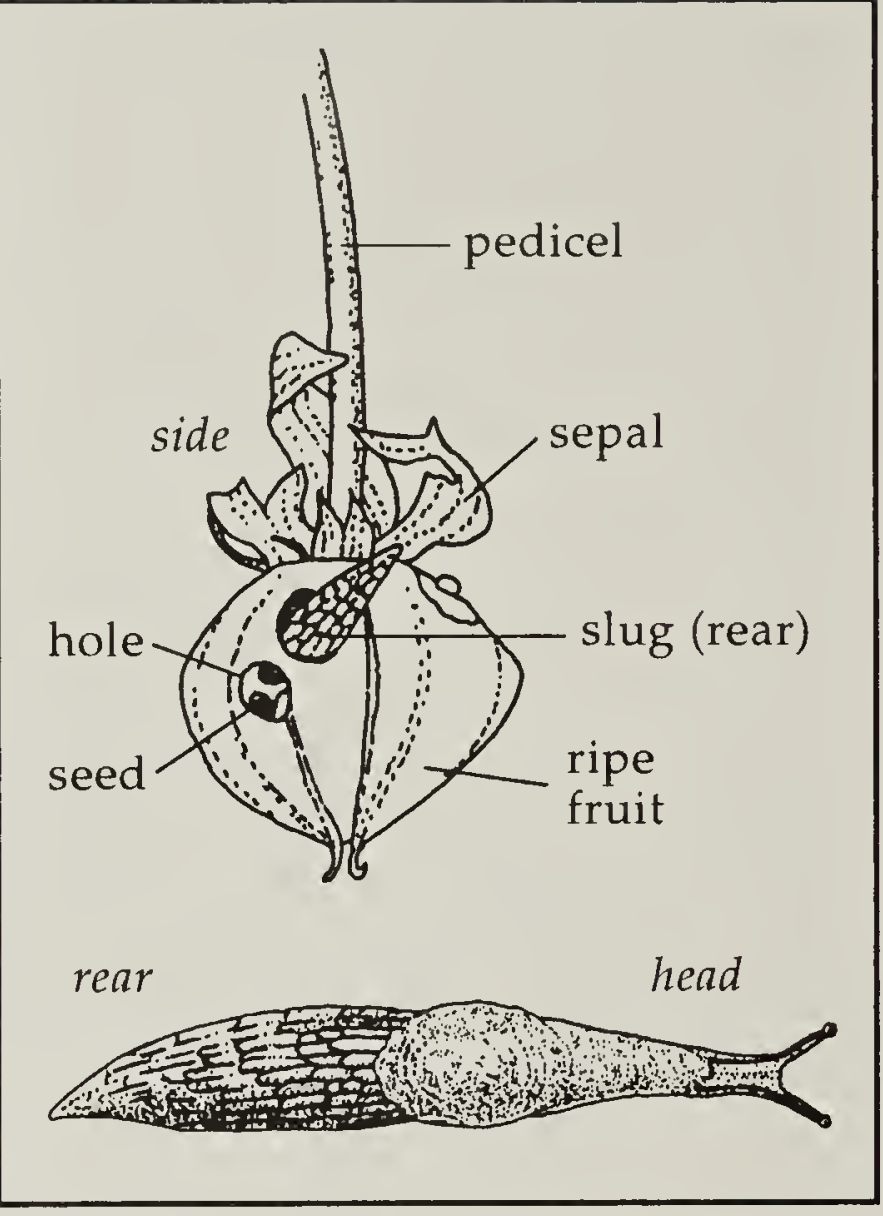

Figure 26. A grey woodland siug (Arion sp.) feeding on elaisosomes through a hole in a fallen ripe fruit of Trillium cernuum (above). $x$ 1. Dorsal view of slug (below). $x 2.5$

\section{Ant dispersal}

The dispersal of seeds of Trillium species by ants has been known for decades. ${ }^{13,14}$ Dispersal tends to reduce competition between seedlings and increases their growth and survival. ${ }^{19}$ The seed itself is not eaten, only discarded, but the large, lipid-rich elaiosome attached to each seed is an attractive food source (Fig. 10). The fatty acid component of the lipids has been analysed in the elaiosome and seed for the pedicillate species in North America. ${ }^{43}$ The chemical composition of elaiosomes varies with species but why some are attractive to some ants remains unclear. ${ }^{25}$

My brief experiment on ant dispersal began at $1530 \mathrm{~h}$ on 21 July 2001 . I tore open a nearly ripe fruit and scattered about 15 seeds, with elaiosomes attached, directly onto an active colony of Common Carpenter Ants. ${ }^{46}$ Seeds were quickly discovered, picked up and carried away from the $40 \mathrm{~cm}$ wide earthen colony. For $(n=8)$ trips the mean 
distance each ant carried a seed was $1.9 \mathrm{~m}$ $(0.4-3.5)$. The open forest floor made it easy to visually follow the pale yellow elaiosome against the dark earth and scant debris. Ants made no attempt to remove or eat the elaiosome. Away from the nest the seed was dropped and the ant headed back to the colony. Centrally located along a natural path, this was the only ant colony found in the Whip-poor-will-flower population. Ants were not observed elsewhere in the forest during May through September, either on the ground, vegetation, or me. By early July there was little surface activity visible in the colony, although the carpenter ants were busy underground. By the time fruit ripened in mid-August and was about to fall, the ant colony appeared abandoned. Three other colonies about 150 $m$ away on the edge of a nearby woods were also abandoned in early August. No ants were observed at or near any fallen fruit, and are not considered a source of seed dispersal in this $T$. cernuum population.

Seed dissemination by ants has been reported in Ohio for Dwarf White Wakerobin, in northern California for Western Wakerobin, and in New York State for Stinking-benjamin, Large-flower Wakerobin, (T. grandiflorum) and Painted Wakerobin, (T. undulatum). ${ }^{31,28,16}$ In New York, at least four species of ants were involved including the Common Carpenter Ant, Camponotus pennslyvanicus, which ignored the seeds. ${ }^{16}$

Once an ant removes a seed and elaiosome from the fallen berry, it is carried away to an underground nest. Sometimes the elaiosome is quickly removed leaving the discarded seed close to the parent plant. Trillium seeds in Japan were transported a mean distance of $60 \mathrm{~cm}$ (maximum $3.3 \mathrm{~m}$ ) by five ant species. ${ }^{32}$ In Australia, the mean carry was $2.1 \mathrm{~m}$ for three ant species. ${ }^{\prime}$ Overall, seed dispersal is dependent on the number of ants present since chance encounters are an important factor as is the distance to the ant's nest, i.e., how much work the ant must do and over what kind of terrain. ${ }^{41}$
In south-western Oregon, over four summers, ants were never observed carrying Western Wakerobin seeds in the Siskiyou Mountains. Instead Yellow Jackets, Vespula vulgaris, transported seeds with elaiosomes to distances $>30 \mathrm{~m}$ from the fruit. ${ }^{23}$ To the east, Yellow Jackets, $V$. flavopolosa and $V$. maculifrons, transported elaiosome-bearing seeds of Little-sweet-Betsy, (T. cuneatum), Bashful Wakerobin, (T. catesbaei), and Painted Wakerobin in the Blue Ridge Mountains of North and South Carolina. ${ }^{47}$ A wasp would grasp the seed/elaiosome using its six legs and either fly out of sight $(>20$ $\mathrm{m}$ ), or alight on a nearby shrub, chew off the elaiosome, let the seed fall to the forest floor and fly away with the elaiosome. In the latter case, the seeds without their elaiosomes were recovered at a mean distance of $1.4 \mathrm{~m}$ $(0.1$ - 2.6) from the parent plant. Although Yellow Jackets, Vespa germanica, occur in my study area in August, I did not observe any trillium seed dispersal by wasps.

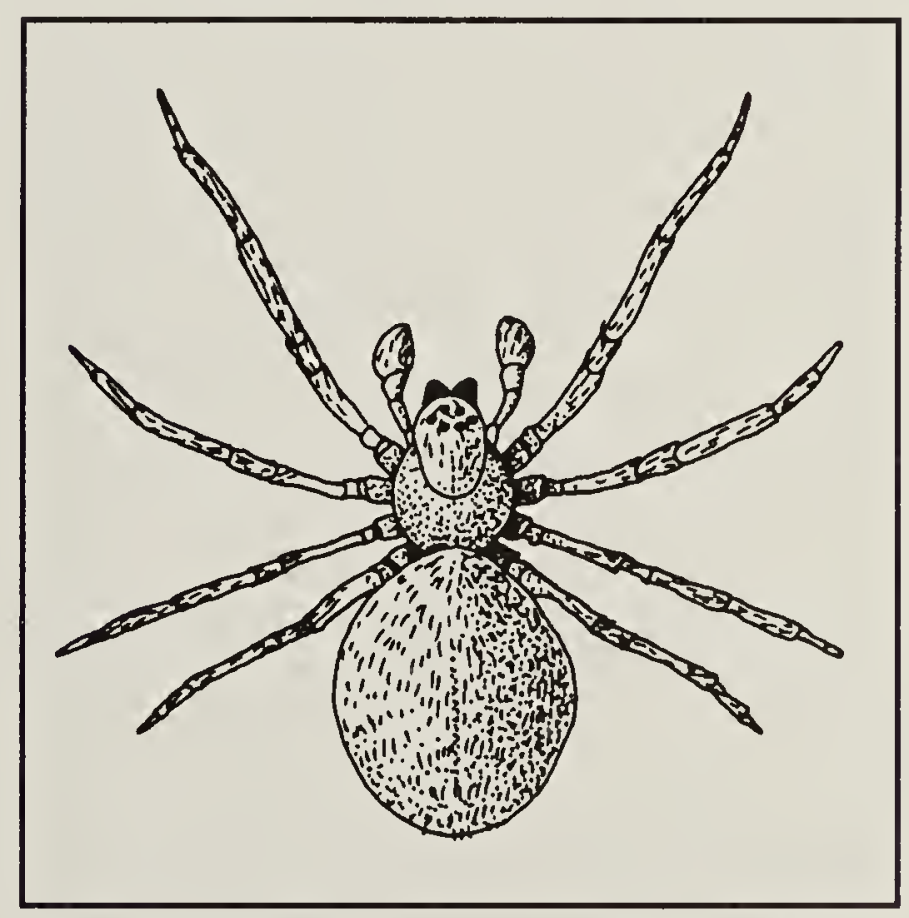

Figure 27. A grey spider often found among the wilted petals and green sepals of the Whip-poor-will-flower in August and September. $x 10$

When collecting ripe fruit during August of both years, it became apparent that a grey spider, about $5 \mathrm{~mm}$ long (Fig. 27), resided at the base of some fruit among the sepals and petal remains. Strands of webbing around the fruit base held various dead insects 2-3 
mm long. Several spiders were collected in August but their immaturity prevented identification.

\section{Acknowledgments}

I would like to thank Anne Adkins for the use of her dissecting microscope which permitted small plant parts to acquire some detail when drawn and described. Richard Staniforth provided ideas on quadrat layout and a sheet of random numbers. Bruce Ford alerted me to the book, Trilliums, by the Cases. Mark Elliot provided 100 plastic markers which were used to re-locate plants the second year. Karin Newman and two anonymous reviewers commented on the manuscript. David Scott provided wooden dowels which were used to mark the boundaries of the quadrats. Howard Clase in Newfoundland clarified the range of the Whip-poor-will-flower in Labrador. Staff at the National Museum of Nature in Ottawa, Ontario identified the black ant and Yellow Jacket but had no specific suggestion for the immature grey slug, grey spider or milliped. I am equally grateful to botanists and curators associated with these herbaria: ACAD, BH, BKL, CANM, CM, DAO, EIU, GLFC, GMNP, HAM, IND, ISC, LKHD, MAINE, MIL, MMNM, MT, MU, MVSC, NBM, NA, NCU, ND, NEBC, NSPM, NYS, PH, UCHT, ULF, UNB, UNCC, VPI, WAT, WET, WIN, WVA, WVA, and WVW. They responded to my letter of inquiry on $T$. cernuum in their area and provided information about its range from their herbarium or local reference books. The Manitoba Naturalists Society permitted me to prepare this manuscript on their computer. This two-year study was initiated and financed by the author.

1.ANDERSEN, A.N. 1988. Dispersal distance as a benefit of myrmecochory. Oecologia (Berlin) 75:507511 .

2.ANDERSON, R.C. 1944. Height of White-flowered Trillium (Trillium grandiflorum) as an index of deer browsing intensity. Ecological Applications 4:104109.
3.ANGELO, R., and D.E. BOUFFORD. 2000. Atlas of the flora of New England: Monocots except Poaceae and Cyperaceae. Rhodora 102-119.

4.BARKLEY, T.M. (ed.). 1977. Atlas of the flora of the Great Plains. The Great Plains Flora Association. Iowa State University Press, IA.

5.BRANDT, R.P. 1916. Notes on the California species of Trillium L. III Season changes in Trillium species with special reference to the reproductive tissues. California Berkeley Publication of Botany 7:39-68.

6.CASE, JR., F.W., and R.B. CASE. 1997. Trilliums. Timber Press, Portland, OR.

7.CATLING, P.M., D.S. ERSKINE, and R.B. MACLAREN. 1985. The plants of Prince Edward Island, with new records, nomenclatural changes, and correction and deletions. Publication 1789, Research Branch, Agriculture Canada.

8.DAVIS, M.A. 1981. The effect of pollinators, predators, and energy constraints on the floral ecology and evolution of Trillium erectum. Oecologia (Berlin) 48:400-406.

9.DEAM, C. 2002. $4^{\text {th }}$ printing. Flora of Indiana. The Blackburn Press, Caldwell, NJ.

10.DE VRIES, B. 1973. Nodding Trilliums in eastern Saskatchewan. Blue Jay 31:214-216.

11.EAMES, A.J., and K.M. WIEGAND. 1923. Variations in Trillium cernuum. Rhodora 25:189-191.

12.FORSYTH, A. 1919. Mammals of North America: temperate and arctic regions. Firefly Books, Buffalo, NY and Willowdale, ON.

13.GATES, B.N. 1940. Dissemination by ants of the seeds of Trillium grandiflorum. Rhodora 42:194-196.

14.GATES, B.N. 1941. Observations in 1940 on the dissemination by ants of the seeds of Trillium grandiflorum. Rhodora 43:206-207.

15.GREAT PLAINS FLORA ASSOCIATION. 1986. Flora of the Great Plains. University Press of Kansas, Lawrence, KS.

16.GUNTHER, R.W., and J. LANZA. 1989. Variation in attractiveness of Trillium diaspores to a seed-dispersing ant. The American Midland Naturalist 122:321-328.

17.HANSAWA, F.M., and S. KALISZ. 1993. The relationship between age, size, and reproduction in Trillium grandiflorum (Liliaceae). American Journal of Botany 80:405-410.

18.HEATLEY, M. 1916. A study of the life history of Trillium cernuum L. Botanical Gazette 61:425-429. 
19.HIGASHI, S., S. ISUYUZAKI, M. OHARA, and F. ITO. 1989. Adaptive advantages of ant-dispersed seeds in the myrmecochorous plant Trillium tschonoskii (Liliaceae). Oikos 54:389-394.

20.HINDS, H.R. 2000. Flora of New Brunswick, $2^{\text {nd }}$ ed. Department of Biology, University of New Brunswick, Fredericton, NB.

21.IRWIN, R.E. 2000. Morphological variation and female reproductive success in two sympatric Trillium species: evidence for phenotypic selection in Trillium erectum and Trillium grandiflorum (Liliaceae). American Journal of Botany 87:205-214.

22.JOHNSON, W.C. 1970. Trillium cernuum L. and Geranium maculatum L.: new for South Dakota. Rhodora 72:554.

23.JULES, E.S. 1996. Yellow Jackets (Vespula vulgaris) as a second seed dispenser for the myrmecochorous plant, Trillium ovatum. The American Midland Naturalist 135:367-369.

24.KARTESZ, J. (no date, search internet under BONAP, Biota of North America Program). University of North Carolina, Chapel Hill, NC.

25.LANZA, J., M.A. SCHMITT, and A.B. AWAD. 1992. Comparative chemistry of elaiosomes of three species of Trillium. Journal of Chemical Ecology 18:209-221.

26.LAPOINTE, L. 1998. Fruit development in Trillium. Plant Physiology 117:183-188.

27.MAHER, R.V., G.W.ARGUS, V.L. HARMS, and J.H. HUDSON. 1979. The Rare Vascular Plants of Saskatchewan, Syllogeus No. 20. National Museum of Natural Sciences, National Museums of Canada, Ottawa, ON.

28.MESLER, M.R., and K.L. LU. 1983. Seed dispersal of Trillium ovatum (Liliaceae) in second-growth redwood forests. American Journal of Botany 70:14601467.

29.MOHLENBROCK, R.H., and D.M. LADD. 1978. Distribution of Illinois vascular plants. Southern Illinois University Press, Carbondale, IL.

30.MORTON, J.K., and J.M. VENN. 2000. The flora of Manitoulin Island and the adjacent islands of Lake Huron, Georgian Bay and the North Channel. 3rd ed. Department of Biology, University of Waterloo, Waterloo, ON.

31.NESOM, GL., and J.C. LA DUKE. 1985. Biology of Trillium nivale (Liliaceae). Canadian Journal of Botany 63:7-14.

32.OHARA, M., and S. H1GASHI. 1987. Interference by ground beetles with the dispersal by ants of seeds of Trillium species (Liliaceae). Journal of Ecology 75:1091-1098.
33.OWNBEY, G.B., and T. MORLEY. 1991. Vascular plants of Minnesota, a checklist and atlas. University of Minnesota Press, MN.

34.PHILLIPS, D. 1990. The climates of Canada. Canadian Government Publishing Centre, Supply and Services Canada, Ottawa, ON.

35.PRINGLE, J.S. 1984. Trilliums of Ontario. Technical Bulletin No. 5. $3^{\text {rd }}$ ed. Royal Botanical Gardens, Hamilton, ON.

36.RHOADES, A.F., W.M. KLEIN, JR., and J.E. KLEIN. 1993. The vascular flora of Pennslyvania: annotated checklist and atlas. American Philosophical Society, Philadelphia, PA.

37.RINGIUS, G.S., and J.G. CHMIELEWSKI. 1987. Morphological variation within and among six populations of Trillium erectum in southern Ontario. Canadian Journal of Botany 65:2450-2457.

38.ROLAND, A.E., and E.C. SMITH. 1969. The flora of Nova Scotia. The Nova Scotia Museum, Halifax, NS.

39.ROULEAU, E., and G. LAMOUREUX. 1992. Atlas of the vascular plants of the island of Newfoundland and the island of Saint-Pierre-et-Miquelon. Fleubec Press, QC.

40.SAMEJIMA, J., and K. SAMEJIMA. 1962. Studies on eastern Asiatic Trillium (Liliaceae). Acta Horti Gotoburgensis 25:157-257.

41.SHAVER, J.M. 1957. Some notes on Trillium stamineum Harbison in Tennessee. Journal of the Tennessee Academy of Science 32:169-184.

42.SMITH, B.H., P.D. FOREMAN, and A.E. BOYD. 1989. Spatial patterns of seed dispersal and predation of two myrmecochorous forest herbs. Ecology 70:16491656.

43.SOUKUP, V.G, and R.T. HOLMAN. 1987. Fatty acids of seeds of North American pedicillate Trillium species. Phytochemistry 26:1015-1018.

44.TAKAHASHI, M. 1982. Pollen morphology in North American species of Trillium. American Journal of Botany 69:1185-1195.

45.VOSS, E.G. 1972. Michigan flora, part 1. gymnosperms and monocots. Cranbrook Institute of Science and University of Michigan Herbarium, Ann Arbor, MI.

46. WHEELER, G.C., and J. WHEELER. 1963. The ants of North Dakota. University of North Dakota, Grand Forks, ND.

47.ZETTLER, J.A., T.P. SPIRA, and C.R. ALLEN. 2001. Yellow Jackets (Vespula spp.) disperse Trillium (spp.) seeds in eastern North America. The American Midland Naturalists 146:444-446. 